Revue de sciences sociales sur les arts, la culture et les idées

\title{
Failed Careers?
}

Sociogenesis and Appropriations of a Bifurcation: The Case of Alumni of the École normale supérieure who Teach in Secondary Education

Des carrières ratées? Sociogenèses et appropriations d'une bifurcation: le cas des anciens élèves des ENS enseignant dans le secondaire ¿Carreras fracasadas? Socio-géneris y apropiaciones de una bifurcación : el caso de los ex alumnos de Escuelas normales superiores que son profesores en secundaria

\section{Pierre Bataille}

Translator. Delaina Haslam

\section{(2) OpenEdition}

\section{Journals}

Electronic version

URL: http://journals.openedition.org/bssg/114

DOI: $10.4000 /$ bssg. 114

ISSN: 2490-9424

\section{Publisher}

Presses universitaires de Vincennes

Electronic reference

Pierre Bataille, "Failed Careers?", Biens Symboliques / Symbolic Goods [Online], 1 | 2017, Online since 15 October 2017, connection on 04 March 2021. URL: http://journals.openedition.org/bssg/114 ; DOI: https://doi.org/10.4000/bssg.114 

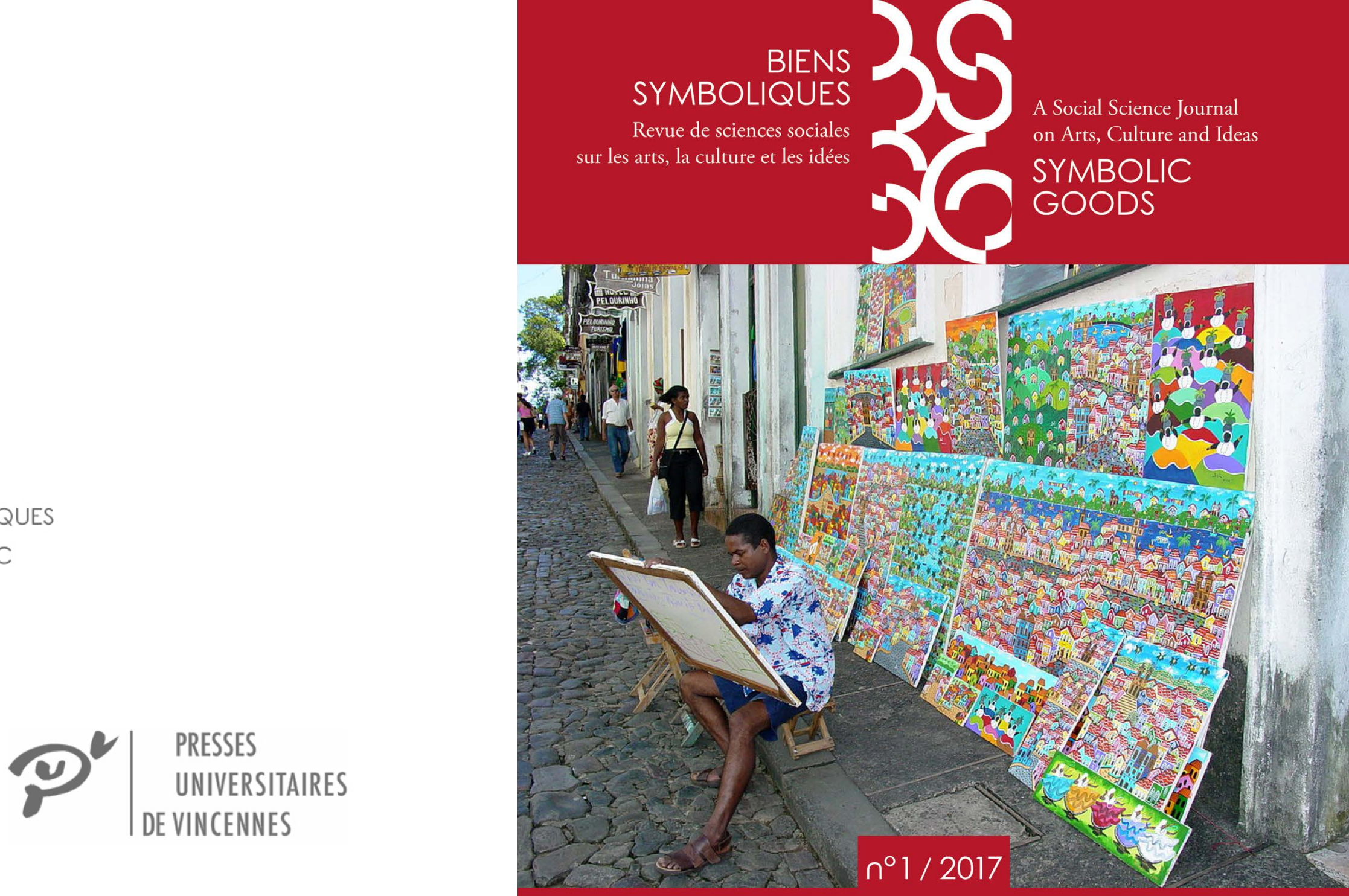

\section{Artistes ordinaires \\ Ordinary Artists}




\section{Des carrières ratées ? Failed Careers?}

Sociogenèses et appropriations d'une bifurcation : le cas des anciens élèves

des ENS enseignant dans le secondaire

Sociogenesis and Appropriations of a Bifurcation: The Case of Alumni of the École normale supérieure who Teach in Secondary Education

Pierre Bataille

traduction | translation

Delaina Haslam 
Bulletin de l'Association amicale des élèves et anciens élèves des Écoles normales supérieures de Lyon, Fontenay-aux-Roses, Saint-Cloud et Fontenay/Saint-Cloud

Couverture du $\mathrm{n}^{\circ} 2$ de 1991 (gauche) et page $17 \mathrm{du} \mathrm{n}^{\circ} 2$ 1992 (droite). Au début des années 1990, l'association des ancien.ne.s élèves des ENS de Fontenay - Saint-Cloud - Lyon publie une série de numéros sur " dans l'entreprise ", l'audiovisuel " ou "dans l'écriture ". Ces numéros ont provoqué nombre de réactions courroucées dans le courrier des lecteurs. Ces lettres, semblables à celle présentée ici, se montraient sensibles à l'importance de la mission "pédagogique " des ENS pour la formation des futur.e.s enseignant $\cdot e \cdot s$

() Illustration construite à partir des archives numérisées du bulletin des ancien-ne's élèves des ENS
Bulletin of the friendly association of the students and former students of the Lyon, Fontenay-aux-Roses, Saint-Cloud and Fontenay/Saint-Cloud Écoles normales supérieures

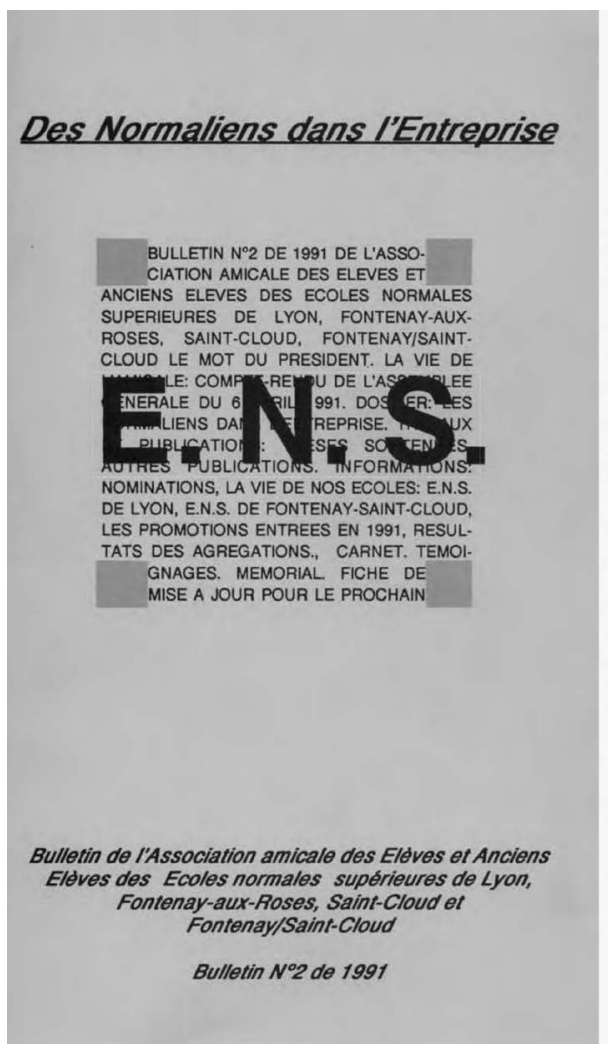

Courrier reçu

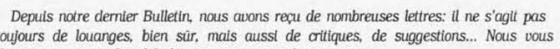

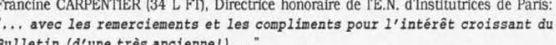
Serge DUNIS $(68 \mathrm{LSCl})$ a Tahitit " "... C'est un platsir de recevoir les bulleting

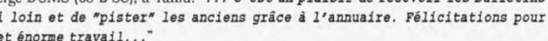

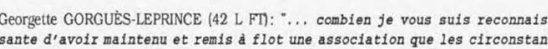
ces et le changenent de pôles renda ient très vulnérab

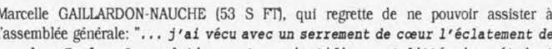

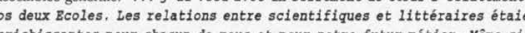

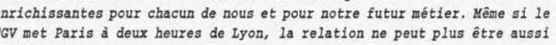

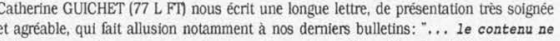
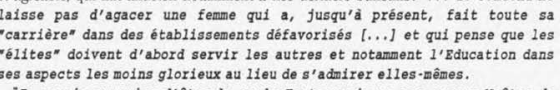

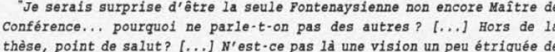

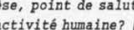

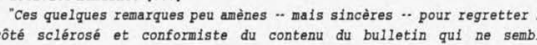
absolunent pas en prise avec la vie de 1'Ecole aufourd' hui.. [.... les

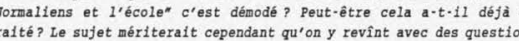

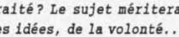
Cloud-Lyon former students the "normaliens in companies,
1991 \#2 cover (left) and page 17, 1992 \#2 (right). At the beginning of the 1990s', the association of the ENS Fontenay-Saintpublished a series of issues on "in the audiovisual industry," or "in the writing field" causing quite a few irate letters, similar to this one and written by readers attached to the "educational" commitment of the ENS to train future teachers. (c) Illustration made out of the digital archives of the Bulletin of the friendly association of the ENS former students. 


\section{Introduction}

Dans Mon oncle d'Amérique, film d'Alain Resnais sorti en 1980 , le réalisateur français nous invite à suivre trois parcours de vie entrecroisés, dont celui de Jean Le Gall, ancien élève de l'École normale supérieure [ENS] (voir encadré 2) et agrégé d'histoire, devenu haut fonctionnaire puis écrivainpolémiste après un court passage dans l'enseignement secondaire, duquel il a réussi à s'extraire grâce aux relations d'un de ses anciens camarades de promotion. Pour un film qui prétend mettre en scène les « mouvements » des êtres humains au sein d'un espace particulier, un tel choix peut paraître curieux, tant les parcours semblables à celui de Le Gall sont extrêmement minoritaires parmi les élèves des ENS. En effet, leur principal débouché reste l'enseignement et la recherche, hier (Barbé et Luc 1982 ; Sirinelli 1988) comme aujourd'hui (Bataille 2014 ; Baudelot, Raux, Ritz, Vinh 2005 ; Pavis 2013). Ce tropisme élitiste n'est bien entendu pas propre à Resnais et traverse nombre de productions culturelles ou médiatiques où sont mis en scène des élèves de grandes écoles - et plus généralement des personnages issus de formations sélectives prestigieuses ${ }^{1}$. Elles donnent une image tronquée de ces espaces sociaux et nourrissent certaines «légendes dorées » mais plus souvent «noires » (Darmon 2013 : 8-11) sur le fonctionnement des établissements sélectifs prestigieux. Cette mise en scène des «belles carrières » participe également, à l'échelle des écoles, à faire accepter aux élèves et futurs élèves des

1 On pourrait ici citer, pour le cas des États-Unis, l'exemple des puissants " clubs secrets " de Harvard, régulièrement mis en scène dans des fictions littéraires ou cinématographiques (Grousset-Charrère, 2012).

\section{Introduction}

In the 1980 Alain Resnais film My American Uncle, the French director invites us to follow three interconnected stories. One of these concerns Jean Le Gall, a former student of the École normale supérieure (ENS-see box 2) who has passed the Concours d'agrégation (a competitive teaching exam) in history, and becomes a senior civil servant and then a writer/ polemicist following a short spell in secondary education, from which he has managed to escape thanks to the contacts of one of his former classmates. For a film which aims to highlight the "movement" of human beings within a particular space, this may seem a strange choice since Le Gall's career path is extremely rare among ENS students. Indeed, teaching and research remain the schools' major outlet-today (Barbé \& Luc 1982; Sirinelli 1988), as was the case in the past (Bataille 2014; Baudelot, Raux, Ritz, Vinh 2005; Pavis 2013). This elitist tropism is not, of course, unique to Resnais, it graces numerous examples of cultural and media production that feature students from grandes écoles (France's top higher education institutions) - and, more generally, characters who have been through a prestigious, selective education ${ }^{1}$. Such portrayals give an incomplete picture of these social spaces and feed certain myths, more often than not giving a negative perspective (Darmon 2013: 8-11) on the way prestigious, selective institutions work. The foregrounding of distinguished careers also plays a role-at the level of schools - in making students and future students of elite institutions accept a

1 We could cite here, in the case of the United States, the example of Harvard's powerful "secret clubs," which regularly feature in literary and cinematographic depictions (Grousset-Charrère, 2012). 
institutions d'élite un processus drastique de sélection, alors même qu'une large partie d'entre eux et elles $^{2}$ sont voués à occuper des positions professionnelles plus ordinaires que les brillantes réussites mises volontiers en exergue par les écoles et leurs représentants (Bourdieu 1989 : 160).

II faut par ailleurs relever que les travaux sociologiques et historiques menés sur les parcours d'élèves de grandes écoles ont longtemps souffert de ce même tropisme élitiste.

En s'intéressant en priorité aux établissements les plus prestigieux (l'École polytechnique, I'ENS d'Ulm, l'École nationale d'administration [ENA] ou encore l'École des hautes études commerciales [HEC]) et principalement aux liens qu'entretiennent les grandes écoles avec les fractions supérieures des sphères économiques, politicoadministratives ou académiques, les recherches menées sur les écoles d'élite françaises et leurs publics ont longtemps davantage contribué à mettre en lumière « l'exception » française plutôt que la « règle» (Marry 2004 : 66). Sans négliger les apports heuristiques fondamentaux quant au fonctionnement des sommets de l'espace social national et international de ces travaux, on peut relever qu'ils contribuent à « suritualiser » (Goffman 1977) l'extra-ordinarité des parcours d'anciens de grandes écoles, renforçant la coupure symbolique déjà existante entre le petit nombre d'élus intégrant les formations sélectives en France et le reste de la population. II faut également souligner que ce tropisme

2 Bien que, tout au long de cet article, nous parlions d'hommes et de femmes, par commodité de lecture, nous utiliserons le masculin pour désigner l'ensemble de la population étudiée. drastic selection process, even though many of them ${ }^{2}$ are destined to fill professional roles that are more ordinary than the brilliant successes readily showcased by schools and their representatives (Bourdieu 1998).

We should also notethat sociological and historical explorations of the career paths of grande école students have long been guilty of this same elitist tropism. By focusing on the most prestigious establishments (the École polytechnique, ENS d'Ulm, the École nationale d'administration [ENA], and the École des hautes études commerciales [HEC]-and primarily on the links grandes écoles maintain with the upper fractions of the economic, political-administrative, and academic spheres-research carried out on elite French schools has long contributed more to exposing the French "exception" rather than the "rule" (Marry 2004: 66). While acknowledging these works' fundamental heuristic contributions regarding the upper limits of the national and international social sphere, we can note that they have helped to "hyper-ritualize" (Goffman 1977) the extraordinariness of the careers of former grandes école students, reinforcing the symbolic rupture which already exists between the few chosen candidates admitted into selective education in France and the rest of the population. It is also important to highlight that this elitist tropism is not unique to French sociology: to give just two examples, in the United States (Karabel 2005; Stevens

2 Although men and women are discussed throughout this article, we will use the masculine to designate the whole of the population studied for the sake of brevity. 
élitiste n'est pas propre à la sociologie française : pour ne citer que ces deux exemples, aux États-Unis (Karabel 2005 ; Stevens 2009) comme en Grande-Bretagne (Bond 2012 ; Soares 1999 ; Zimdars, Sullivan, Heath 2009), ce sont en priorité les liens entre les établissements les plus prestigieux (Harvard et la formation Ox-bridge la plupart du temps) et les fractions dominantes de l'espace social qui ont le plus souvent été choisis comme objet d'étude.

Certaines recherches, s'intéressant à des destinées d'élèves plus ordinaires (Castets-Fontaine 2011 ; Lambert 2010 ; Pasquali 2014 ; Pierrel 2015) et à des écoles autres que celles de la « grande porte » (Blanchard 2015 ; Marry 2004 ; Quéré 2015) contribuent à nuancer l'impression de « surcohérence élitaire » (Eymeri 2001:2) que peuvent donner nombre de travaux classiques sur les élites françaises. En analysant les parcours d'anciens élèves d'un groupe de grandes écoles prestigieuses mais de second rang (les ENS de Fontenay, Saint-Cloud et Lyon) qui embrassent une carrière professionnelle relativement ordinaire (celle d'enseignant du secondaire), on entend donc ici éclairer un aspect relativement méconnu du double travail de production et de reproduction sociale opéré par les écoles d'élite.

Alors que certains anciens élèves des ENS devenus enseignants dans le secondaire se décrivent - non sans humour-comme des «normaliens ratés » par rapport à leurs camarades ayant suivi une carrière académique, on peut se demander si un tel parcours professionnel est nécessairement identifiable à une relégation. II s'agira de rendre compte des facteurs qui participent à amplifier ou à atténuer ce sentiment
2009) as well as the UK (Bond 2012; Soares 1999; Zimdars, Sullivan, Heath 2009) it is primarily links between the most prestigious establishments (usually Harvard and Oxbridge) and the dominant fractions of the social space which have been chosen most often as objects of study.

Certain research focusing on the destiny of more ordinary students (Castets-Fontaine 2011; Lambert 2010; Pasquali 2014; Pierrel 2015) and on schools other than the most eminent (Blanchard 2015; Marry 2004; Quéré 2015) has helped bring nuance to the impression of "elite over-coherence" (Eymeri 2001: 2) which many classic works on French elites can give. By analysing the trajectories of former students of a group of grandes écoles which, although prestigious, are of secondary importance (the ENS of Fontenay, Saint-Cloud, and Lyon) and who embrace a relatively ordinary professional career (that of a secondary school teacher), we thereby intend in this paper to shed light on a relatively unknown aspect of the dual effect of social production and reproduction as orchestrated by elite schools.

While some former ENS students who have become secondary school teachers describe themselves - not without humour-as "failed normaliens" (normalien is the label given to students of the École normale) in relation to their peers who have followed an academic career, we can consider whether such a career can necessarily be perceived as relegation. We aim to explain the factors that help to exacerbate or 
de « ratage » et d'analyser les différentes manières de négocier avec soi-même mais aussi son entourage plus ou moins proche (famille, camarades de promotion, collègues) cette inscription durable dans une carrière enseignante. Plus généralement, alors que la construction sociale du talent et de la réussite a fait l'objet de nombreux travaux récents en sociologie francophone (Darmon 2012 ; Menger 2009 ; Schotté 2012), nous proposons un point de vue complémentaire, en nous intéressant à un cas où le processus de consécration ne s'est pas déployé jusqu'à son terme. II s'agira pour nous d'analyser la sociogenèse de ces bifurcations et de mettre en lumière leur incidence sur les représentations des individus qui les traversent.

Les analyses développées ici sont tirées de données récoltées dans le cadre d'un travail de thèse (Bataille 2014) et sont présentées dans l'encadré 1. L'article porte prioritairement sur les personnes ayant occupé un poste dans l'enseignement secondaire pendant une majeure partie de leur carrière. Cette précision est importante tant nombre d'anciens élèves ont fait un court crochet de quelques années, voire de quelques mois ou de quelques semaines, dans l'enseignement secondaire au début de leur carrière pour « patienter [...] avant d'obtenir un poste [dans le supérieur] ", selon l'expression de Gabriel $(\mathrm{L}, \mathrm{MC}, \text { Paris, Fam- })^{3}$. Ces expériences de courte durée seront traitées marginalement.

3 Quatre informations sur la situation des personnes citées seront données systématiquement à la suite de leur prénom. Premièrement, sera indiquée la filière de l'école dont elles sont issues : L (littéraire) ou $S$ (scientifique). Deuxièmement, le type de profession que les personnes interrogées occupent PU/DR si elles sont Professeur.e.s des Universités ou Directeur.trice.s de mitigate this feeling of "failure," and analyse the different ways of negotiating a permanent commitment to a career in teaching - with oneself, but also with one's relatively close entourage (family, classmates, colleagues). More generally, while the social construction of talent and success has been the subject of much recent work in French sociology (Darmon 2012; Menger 2014; Schotté 2012), we propose a complementary perspective by focusing on a case in which the recognition process is not carried through to conclusion. We set out to analyse the sociogenesis of these bifurcations, and to highlight their impact on the representations of individuals who cross them.

The analysis developed here is taken from data collected within the framework of a thesis (Bataille 2014), presented in box 1 . The article focuses primarily on those who have held a position in secondary education for the majority of their career. This is an important clarification since many former students have done a stint in secondary teaching of a few years, or even months or weeks, at the beginning of their career while they "wait... for a position [in higher education]," as expressed by Gabriel (A, L, Paris, Fam-) ${ }^{3}$. Such shortterm experiences will be dealt with briefly.

3 Four pieces of information regarding the situation of persons cited will automatically be given after their first name. First, the course of study taken will be indicated: A (arts) or S (science). Second, the type of occupation held by those interviewed: P/RD for University Professor or Research Director; L/R for Lecturer or Researcher; CPGE denotes that they teach classes préparatoires aux grandes écoles, which is post-baccalauréat training to prepare students for the grandes écoles; "Sec" if they teach at secondary level; 


\section{Encadré 1. Méthodologies et données}

L'analyse est fondée sur le croisement de deux enquêtes : la première, quantitative ; la deuxième qualitative et construite sur l'exploitation d'entretiens.

Nous avons, en premier lieu, effectué une enquête par questionnaire entre février 2008 et mars 2009 auprès des ancien.ne's élèves des ENS de Fontenay, SaintCloud et Lyon, issus des promotions de 1981 à 1987. La population d'origine comportait 1453 personnes, réparties entre 654 " scientifiques » et 799 " littéraires ». En tout, 418 personnes ont répondu à notre sollicitation, soit un taux de réponse total de $30 \%$. Sous l'angle du sexe, de la spécialisation disciplinaire, de la promotion et de l'origine sociale, la comparaison avec les données publiées par les Écoles et les ministères de tutelle n'indique pas de biais dans notre échantillon.

En second lieu, nous avons effectué une enquête par entretiens semi-directifs auprès de 50 ancien.ne-s de ces promotions. Les personnes participant à cette enquête, rencontrées via leur participationà l'enquête par questionnaire ou par l'intermédiaire d'autres ancien·ne·s, ont été choisies afin d'assurer un éventail de cas aussi large que possible en fonction de cinq critères principaux : le sexe, la discipline, l'origine sociale, le type de profession occupée au moment de l'entretien et la localisation géographique principale dans laquelle s'inscrivait leur activité professionnelle.

Recherche ; MC/CR si elles sont Maîtres-se-s de Conférences ou Chargé.e.s de Recherche ; CPGE si elles sont enseignantes en classes préparatoires aux grandes écoles ; "Sec " si elles sont enseignantes dans le secondaire ; "Autre+ " si elles occupent une profession intellectuelle supérieure non liée à l'enseignement et la recherche ; « Autre- " si elles n'occupent pas une profession supérieure. Troisièmement, le lieu où elles effectuent leur activité professionnelle : Paris ou Province (Prov). Enfin, on trouvera une indication sur le type de familles dont est issue la personne citée : "Fam+ " pour les familles fortement dotées, "Fam $\uparrow$ » pour celles en ascension et " Fam- " pour celles peu dotées. Cette typologie familiale est explicitée dans la première partie de l'article.
Box 1. Methodologies and data

The analysis is supported by two interrelated studies: the first quantitative; the second qualitative and based on the use of interviews.

We first of all carried out a survey in the form of a questionnaire between February 2008 and March 2009 on former students of the ENS of Fontenay, Saint-Cloud, and Lyon who graduated between 1981 and 1987 . The original group contained 1,453 people, divided into 654 "science" and 799 "arts." Overall, 418 people responded to our invitation, or a total response rate of $30 \%$. In terms of sex, disciplinary specialisation, academic year, and social origin, a comparison with data published by schools and the relevant ministry shows no bias in our sample.

We then conducted a survey using semi-structured interviews with fifty former students from these years. Those participating in this survey, who were found by means of their having responded to the questionnaire survey or via other former students, were chosen to ensure as broad a sample of cases as possible on the basis of five main criteria: sex, discipline, social origin, job type at time of interview, and main geographic location in which their professional activity takes place.
"Other+" if they are employed in a higher intellectual occupation not linked to teaching or research; "Other-" if not in a senior role. Third, the place where they conduct their professional activity: Paris or provinces ("Prov"). Finally, an indication is given as to the family background of the person cited: "Fam+"

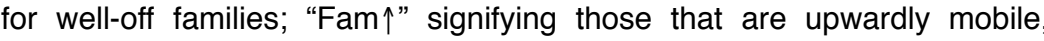
and "Fam-" for the underprivileged. This typology of family background is explained in the first part of the article. 
Dans un premier temps, nous proposerons une description statistique de la fréquence et des conditions de possibilité de telles carrières. Dans un deuxième temps, nous reviendrons sur l'analyse des récits tenus par les anciens élèves ayant fait une large partie de leur carrière dans le secondaire, à propos de leurs premières expériences professionnelles en collège ou en lycée, en essayant d'appréhender dans quelle mesure cet événement a pu représenter un turning point significatif dans leur parcours. Dans un troisième temps, il s'agira d'identifier les stratégies mises en œuvre pour limiter à long terme le sentiment de relégation que peuvent partager les personnes interrogées.

\section{Les conditions sociales d'une carrière minoritaire}

\subsection{Un devenir professionnel de moins} en moins courant

L'image du normalien contraint à « l'apostolat » de la carrière d'enseignant du secondaire nourrit la plupart des débats au sujet de la place des ENS au sein de l'espace de l'enseignement supérieur français. Sous cette image se cache bien souvent une dénonciation du " gâchis » en «matière grise » et en « deniers publics »-pour reprendre le vocabulaire utilisé dans une controverse récente ${ }^{4}-$ que pourrait représenter un avenir professionnel de simple

$4 \quad$ Nous faisons ici référence à la joute ayant opposé, dans les colonnes de la revue Movement \& Sport Sciences, le rédacteur en chef de la revue Didie Delignères (2012) et les représentants de l'association des élèves de la section EPS de l'ENS de Cachan (A3EPS 2013) au sujet des normaliens préférant se consacrer à la pédagogie plutôt qu'à une recherche doctorale.
We first of all propose a statistical description of the frequency and the conditions enabling such careers. Secondly, we will come to analysis of the accounts of former students who have spent the majority of their career in secondary teaching, regarding their first professional experiences at school or college/high school, with the aim of ascertaining the extent to which this event may have represented a turning point in their trajectory. Thirdly, we will attempt to identify the strategies deployed to reduce over the long term the feeling of relegation that those interviewed can feel.

\section{The social conditions of a minority career}

\subsection{An increasingly rare employment choice}

The image of the normalien forced into the "apostolate" of a secondary school teaching career feeds most debates on the subject of the ENS within French higher education. Very often this image is hiding a denunciation of the "waste" of "brainpower" and "public money"-to borrow terms used in a recent controversy ${ }^{4}$ - which a career as a simple high school teacher might represent for normaliens considering, on the one hand, investment by the public authorities to guarantee

$4 \quad$ We are referring here to the clash in the columns of Movement \& Sport Sciences between editor Didier Delignères (2012) and representatives of the students' association of the ENS de Cachan's sport and physical education department (A3EPS, 2013) regarding normaliens who prefer to devote themselves to teaching than to doctoral research. 
enseignant de lycée pour les normaliens compte tenu, d'une part, des investissements consentis par la puissance publique pour assurer la formation des lauréats du concours d'entrée et, d'autre part, du haut degré de sélectivité auquel les élèves se soumettent pour y rentrer. Si cette discussion autour de la fonction des ENS est presque aussi ancienne que la création de ces écoles (Bataille 2014), elle a connu un regain d'intensité ces dernières années, par le biais de la question du remboursement de la formation en cas de rupture de « l'engagement décennal $»^{5}$ (voir encadré 2).

Encadré 2. Les ENS de Saint-Cloud, Fontenay et Lyon
Comme d'autres grandes écoles, notamment l'École
Polytechnique, les ENS sont une création de la période
révolutionnaire en France. Elles visaient initialement
à pourvoir, sur une base méritocratique, le secteur de
l'enseignement en cadres et en enseignants. Durant la
Révolution, cette première ENS - dont la prestigieuse
école de la rue d'Ulm est l'héritière directe - avait ainsi
pour vocation la formation des enseignants du secondaire.
Les autres ENS furent créées par la suite sur un modèle
similaire pour assurer le recrutement et la formation des
enseignants et cadres de l'enseignement primaire supérieur
(Saint-Cloud et Fontenay 1981-1983) et de l'enseignement
technique (Cachan 1912). Créée en 1986, I'ENS de Lyon
est en fait l'héritière des écoles de Fontenay et Saint-Cloud,
qui n'existent plus en tant que telles. Une ancienne antenne
de l'école de Cachan est devenue une ENS à part entière,
l'ENS de Rennes, en 2013.

5 En échange du salaire de fonctionnaire stagiaire qu'ils et elles touchent durant leurs quatre années d'étude dans une ENS, les normaliens et normaliennes sont tenus de travailler au moins dix années consécutives en début de carrière dans la fonction publique. the education of those who pass the entrance exams and on the other, the high degree of selectivity to which students submit themselves to get in. While this debate around the function of the ENS is almost as old as the schools' history (Bataille 2014), it has seen an increase in intensity in recent years owing to the issue of reimbursement of the training in the event of a rupture of the so-called "ten-year commitment ${ }^{5}$ " (see box 2).

Box 2. The Écoles normales supérieures (ENS) of Saint-Cloud, Fontenay, and Lyon

Like other grandes écoles, especially the École polytechnique, the ENS emerged out of the French Revolution. Their original purpose was to provide the education sector with managers and teachers on a meritocratic basis. During the Revolution, the role of this first ENS- of which the prestigious school on Paris's rue d'Ulm is the direct descendent- was thus to train secondary school teachers. The other ENS were then created using a similar model to provide recruitment and training of teachers and managers for primary (Saint-Cloud and Fontenay 1981-1983) and technical education (Cachan, 1912). Created in 1986, the ENS de Lyon in fact descends from the Fontenay and SaintCloud schools, which no longer exist in their original form. A former satellite of the Cachan school became an ENS in its own right, the ENS de Rennes, in 2013.

5 In exchange for the civil servant training salary that they receive during their four years of study at ENS, normaliens are required to work for at least ten consecutive years at the beginning of their career in the public service. 
Malgré ces différences initiales de fonction et de prestige, on observe au cours de la deuxième moitié $d u x^{e}$ siècle un alignement statutaire progressif des trois ENS. Même si des différences de réputation demeurent, la mission principale pour les trois écoles est, depuis 1985, la formation des futurs enseignants-chercheurs. À partir de 1985, les élèves ont ainsi eu la possibilité de candidater après leurs années d'école à des postes spécialement créés pour eux ( A Ancien normalien doctorant »[AND] - devenus après 1989 « Assistant moniteur normalien » [AMN]) permettant aux normaliens thésards de financer leurs premières années de doctorat en échange d'un service d'enseignement dans une université de rattachement.

Le cursus au sein des trois écoles dure quatre années, pendant lesquelles les élèves sont salariés au titre de " fonctionnaires stagiaires ». Ils peuvent suivre des cursus dans des domaines académiques plutôt " scientifiques " (sciences fondamentales) ou plutôt « littéraires 》 (lettres, langues, sciences sociales, humanités). En échange de ces quatre années rémunérées, les élèves s'engagent à travailler au moins durant les dix premières années de leur vie professionnelle dans la fonction publique, la plupart du temps en enseignant, grâce aux concours qu'ils ont pu préparer durant leurs années d'école. Ce concours est le plus souvent l'agrégation, le plus sélectif et prestigieux des concours d'accès au statut d'enseignant dans le secondaire - qui constitue également dans certaines disciplines un critère de recrutement officieux pour faire carrière dans l'enseignement supérieur. Si les élèves rompent cet « engagement décennal », ils et elles s'engagent à rembourser les salaires reçus durant leurs années d'école.

Comme la plupart des grandes écoles, les ENS sont accessibles vers l'âge de vingt ans, sur concours, après deux années ou plus de préparation dans des classes préparatoires aux grandes écoles [CPGE]. Celles-ci
While there were initial differences in function and prestige, the first half of the 20th century saw a gradual alignment in status of the three ENS establishments. While there are still differences in reputation, since 1985 the central mission of the three schools has been the training of future academics. Following their studies, the students have thus had the possibility since 1985 of applying for positions created especially for them ("Ancien normalien doctorant" [Normalien Graduate Doctoral Student], AND - which became "Assistant moniteur normalien" [Normalien Assistant Supervisor], AMN, after 1989) allowing normalien PhD students to finance their first years of a thesis in exchange for teaching at an affiliated university.

The curriculum at the three schools takes four years, during which the students are paid as "trainee civil servants." They may follow curricula in the academic fields of "science" (basic science) or the "arts" (literature, languages, social science, humanities). In exchange for these four paid years, students commit to work for at least the first ten years of their professional lives in public service, usually in teaching positions by way of the competitive recruitment exams they have prepared for during their years of training. This most often consists of the agrégation, which is the most selective and prestigious entrance exam to become a secondary school teacher - and also constitutes in some disciplines an informal recruitment criterion for a career in higher education teaching. If a student fails to honour this "ten-year commitment," he or she must repay the salary received during their school years.

As with the majority of grandes écoles, students can attend the ENS schools from around the age of 20 , via an entrance exam, after two or more years' "preparation" in classes préparatoires aux grandes écoles [CPGE]. These are 
sont des classes spéciales au sein de certains lycées : des enseignants du secondaire y préparent des élèves étroitement sélectionnés. Comme les écoles auxquelles elles préparent, les CPGE s'organisent en filières (littéraires, scientifiques, commerciales...) et sont l'objet de classements informels selon l'exigence de leur recrutement et le prestige des concours que réussissent leurs élèves. Concentrant les moyens matériels, le capital symbolique et la capacité à choisir ses étudiants, le système des classes préparatoires et des grandes écoles constitue le cœur du recrutement de la formation des élites françaises - tandis que la majorité des étudiants se retrouve dans les premiers cycles universitaires.

Il est néanmoins difficile d'établir un constat précis dans la mesure où, jusqu'à récemment, les ENS n'entretenaient pas de base de données à jour quant au suivi de leurs élèves. Les données récoltées dans le cadre de notre thèse montrent néanmoins que, pour les normaliens, la probabilité de se trouver durablement engagés dans une carrière d'enseignant en lycée - voire en collège - est relativement faible (tableau 1). special classes within some secondary schools or colleges through which teachers prepare carefully selected students. Like the schools they are preparing students for, the CPGE are organized into streams (arts, scientific, business, etc.), and are informally setted according to ability depending on their recruitment requirements and the prestige of the exam their students sit. In its concentration of material resources, symbolic capital, and capacity to select students, the system of the classes préparatoires and the grandes écoles constitutes the core of the education recruitment process of the French elite-while the majority of students can be found in the regular university system.

It is, however, difficult to establish specific findings since, until recently, the ENS did not keep an up-to-date database regarding students' progress. Data collected within the framework of our thesis nevertheless show that the likelihood of normaliens finding themselves employed long term in a teaching position in secondary education is relatively low

(table 1) 
Tableau 1. Professions des ancien·ne·s élèves des promotions 1981-1987 une vingtaine d'années après I'ENS (en \% colonne)

\begin{tabular}{|c|c|c|c|c|c|}
\hline Domaines & Positions occupées en 2007-2008 & $\mathrm{L}$ & $\mathrm{s}$ & Total pos. & Total dom. \\
\hline \multirow{7}{*}{$\begin{array}{l}\text { Enseignement } \\
\text { Supérieur et } \\
\text { post-bac, } \\
\text { recherche }\end{array}$} & Professeurs des universités (PU) & 17 & 14 & 15 & \multirow{7}{*}{73} \\
\hline & Directeurs de recherche (DR) & 2 & 14 & 8 & \\
\hline & Maîtres de conférences (MCF) & 38 & 8 & 22 & \\
\hline & Chargés de recherche $(\mathrm{CR})$ & 0 & 10 & 5 & \\
\hline & $\begin{array}{l}\text { Professeurs agrégés rattachés à } \\
\text { l'enseignement supérieur (PRAG) }\end{array}$ & 3 & 6 & 5 & \\
\hline & Enseignants en classes préparatoires & 8 & 27 & 17 & \\
\hline & Enseignants en BTS & 1 & 0 & 1 & \\
\hline \multirow{2}{*}{$\begin{array}{l}\text { Enseignement } \\
\text { secondaire }\end{array}$} & Enseignants de lycée & 13 & 12 & 13 & \multirow[t]{2}{*}{14} \\
\hline & Enseignants de collège & 1 & 0 & 1 & \\
\hline \multirow{4}{*}{$\begin{array}{l}\text { Autres } \\
\text { professions } \\
\text { intellectuelles } \\
\text { supérieures }\end{array}$} & Cadres sup. de la fonction publique & 7 & 4 & 5 & \multirow{4}{*}{11} \\
\hline & Cadres sup. du privé et chefs d'entreprise & 4 & 3 & 4 & \\
\hline & Professions de tradition libérale et & & & & \\
\hline & $\begin{array}{c}\text { professions } \\
\text { artistiques/de l'information }\end{array}$ & 4 & 0 & 2 & \\
\hline \multirow[t]{2}{*}{ Autre } & Retraités et sans emploi & 1 & 0 & 1 & \multirow[t]{2}{*}{2} \\
\hline & Autre & 1 & 0 & 1 & \\
\hline Total (N) & & 214 & 204 & 418 & 418 \\
\hline
\end{tabular}

Lecture : en 2007-2008, $14 \%$ des anciens élèves interrogés étaient enseignants en secondaire.

II apparaît clairement ici que ce sont les domaines de l'enseignement post-bac et la recherche académique - fréquentés par près des trois quarts de nos répondants qui constituent la voie royale des normaliens une vingtaine d'années après I'ENS. On peut néanmoins repérer des différences internes importantes selon le champ disciplinaire de spécialisation, les littéraires étant devenus plus souvent
Table 1. Occupations of former students who graduated between 1981 and 1987 around twenty years after ENS (\%)

\begin{tabular}{|c|c|c|c|c|c|}
\hline Field & Positions held in 2007-2008 & A & $\mathrm{s}$ & Total pos. & Total field \\
\hline \multirow{7}{*}{$\begin{array}{l}\text { Higher education } \\
\text { and post- } \\
\text { baccalauréat } \\
\text { teaching, research }\end{array}$} & Professors $(\mathrm{P})$ & 17 & 14 & 15 & \multirow{7}{*}{73} \\
\hline & Research director (RD) & 2 & 14 & 8 & \\
\hline & Lecturer $(\mathrm{L})$ & 38 & 8 & 22 & \\
\hline & Researcher (R) & 0 & 10 & 5 & \\
\hline & $\begin{array}{l}\text { Teachers having passed the } \\
\text { agrégation exam (PRAG) }\end{array}$ & 3 & 6 & 5 & \\
\hline & Classes préparatoires teachers & 8 & 27 & 17 & \\
\hline & $\begin{array}{l}\text { Brevet de technicien supérieur (BTS) } \\
\text { technician certificate teachers }\end{array}$ & 1 & 0 & 1 & \\
\hline \multirow[t]{2}{*}{ Secondary education } & High school/college teachers & 13 & 12 & 13 & \multirow{2}{*}{14} \\
\hline & Secondary school teachers & 1 & 0 & 1 & \\
\hline \multirow{3}{*}{$\begin{array}{l}\text { Other higher } \\
\text { intellectual } \\
\text { occupations }\end{array}$} & Higher public service administrators & 7 & 4 & 5 & \multirow{3}{*}{11} \\
\hline & $\begin{array}{r}\text { Senior managers in the private sector } \\
\text { and business leaders }\end{array}$ & 4 & 3 & 4 & \\
\hline & $\begin{array}{l}\text { Traditionally liberal occupations, } \\
\text { and arts/information occupations }\end{array}$ & 4 & 0 & 2 & \\
\hline \multirow[t]{2}{*}{ Other } & Retired and unemployed & 1 & 1 & 1 & \multirow{2}{*}{2} \\
\hline & Other & 1 & 1 & 1 & \\
\hline Total (N) & & 214 & 204 & 418 & 418 \\
\hline
\end{tabular}

As can be seen, in $2007-2008,14 \%$ of the former students interviewed were high school/ college teachers.

It is clear here that it is the post-baccalauréat areas of teaching and academic research-in which nearly three quarters of our respondents were engaged in-which constitute the route par excellence for normaliens around twenty years after leaving ENS. We can nevertheless identify significant internal differences within specialization of disciplinary field, with arts graduates having more often become academics, and science graduates slightly more often CPGE teachers in 
universitaires et les scientifiques un peu plus souvent enseignants en CPGE notamment. Les scientifiques semblent également avoir connu des carrières académiques plus rapides que leurs camarades des filières littéraires : la proportion de Professeurs des universités et de Directeurs de recherche est, en effet, plus forte dans leurs rangs. On peut également relever que les littéraires sont plus nombreux et nombreuses parmi le petit contingent d'anciens évoluant dans des professions intellectuelles supérieures nonacadémiques $^{6}$

En revanche, on relève très peu de différences interdisciplinaires concernant l'inscription au long terme dans une carrière d'enseignant en lycée ou en collège. Chez les littéraires comme chez les scientifiques, entre 12 et $14 \%$ des anciens élèves ont durablement emprunté la voie de l'enseignement secondaire. Ce résultat peut a priori étonner. Du fait du nombre important de postes en CPGE scientifiques ${ }^{7}$ et du plus grand éventail de choix qui leur est offert au niveau de la recherche académique ${ }^{8}$, on aurait pu penser qu'ils et elles se détourneraient encore plus massivement des

6 Pour une analyse plus approfondie de ce type de parcours, nous nous permettons de renvoyer à un autre article plus précisément dédié à cette question (Bataille 2013).

7 Les effectifs des CPGE scientifiques étaient près de 3,5 fois supérieurs à ceux des CPGE littéraires en 2002 (Baudelot, Dethare, Hérault, Lemaire, Rosenwald 2003 : 13).

8 En effet, pour les scientifiques, aux postes de MCF dans les universités s'ajoutent les potentiels postes dans un des multiples établissements de recherche publique français, tels que le CNRS, I'INRA, I'INSERM, le CEA, I'INRIA ... alors que pour les littéraires, seule une candidature au CNRS est la plupart du temps envisageable parallèlement aux candidatures à l'université. particular, science graduates also seem to have completed their academic careers more quickly than their peers in the arts stream: the proportion of professors and research directors is in effect higher among their ranks. We can also observe that there is a higher number of arts graduates among the small contingent of former students who are in non-academic higher intellectual roles ${ }^{6}$.

However, there are very few interdisciplinary differences in terms of long-term dedication to teaching in secondary education. Among both arts and science graduates, between 12 and $14 \%$ of former students have taken up the secondary education teaching route for a long period of time. This result may at first be surprising. On the strength of the high number of science CPGE positions ${ }^{7}$ and the wider range of choice offered to them in terms of academic research ${ }^{8}$, we may have assumed that these graduates would avoid secondary education teaching to an even greater extent than their former arts peers. Analysis of the interviews will show that orientation towards secondary teaching cannot in fact be reduced to a pure consequence of a saturated job market or

6 For more thorough analysis of this type of route, we would highlight another article more specifically dedicated to this issue (Bataille, 2013)

7 The number of science CPGE students was nearly 3.5 times higher than that of arts CPGE in 2002 (Baudelot, Dethare, Hérault, Lemaire, Rosenwald, $2003: 13)$

8 Indeed, for science graduates, as well as lectureships at universities, there are potential positions at numerous French public research institutions, such as CNRS, INRA, INSERM, CEA, INRIA, etc.; whereas arts graduates cannot expect to apply anywhere except CNRS in parallel to university applications. 
postes en lycées que leurs anciens camarades littéraires. On verra dans l'analyse des entretiens que l'orientation vers le secondaire ne saurait en effet se réduire à un pur effet de marché de l'emploi saturé et à un choix par défaut, faute d'opportunités professionnelles dans d'autres secteurs.

La figure 1 donne un aperçu chronologique de l'évolution de la fréquence de ces différents devenirs professionnels. Elle montrequ'en plus d'être minoritaire au sein de notre échantillon, la carrière durable dans l'enseignement secondaire est en recul parmi les promotions les plus récentes.

\section{Figure 1. Les devenirs professionnels des anciens} élèves selon la promotion

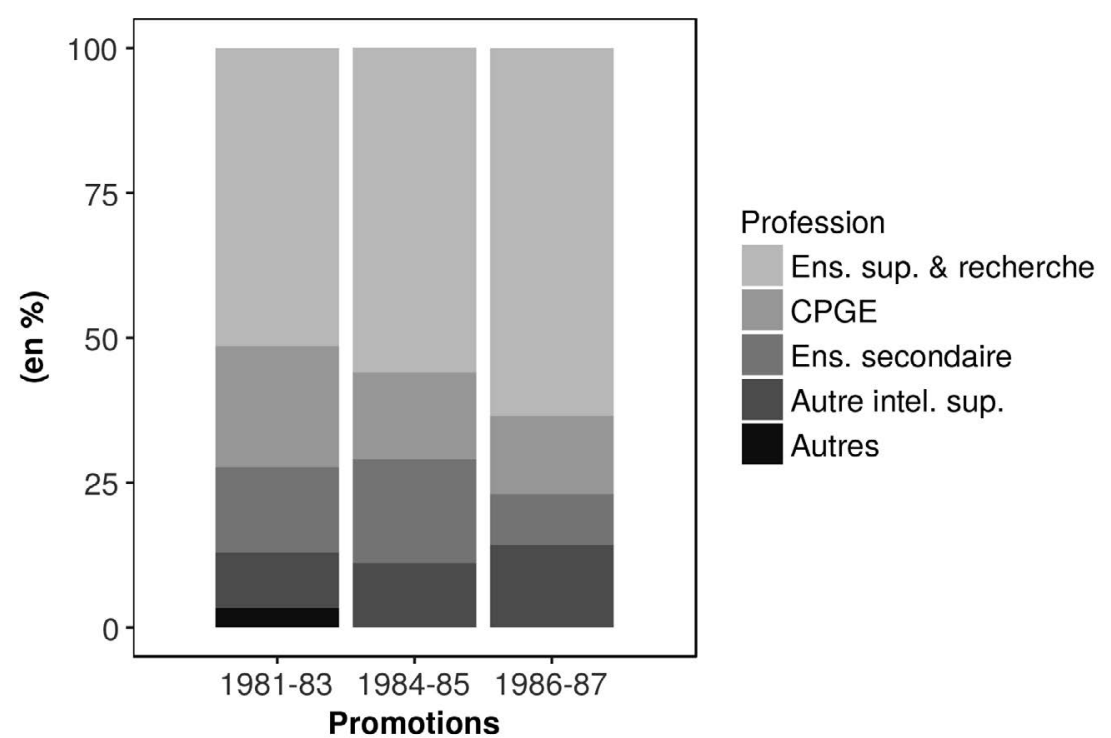

Lecture : $8 \%$ des élèves des promotions de 1986-1987 étaient enseignants en lycée au moment de l'enquête. a default choice owing to a lack of professional opportunities in other sectors.

Figure 1 provides a chronological overview of the evolution of the frequency of each form of employment. It shows that in addition to being in the minority within our sample, a longterm career in secondary education teaching is in decline among students who have graduated most recently.

\section{Figure 1. Occupation of former students according to year of graduation}

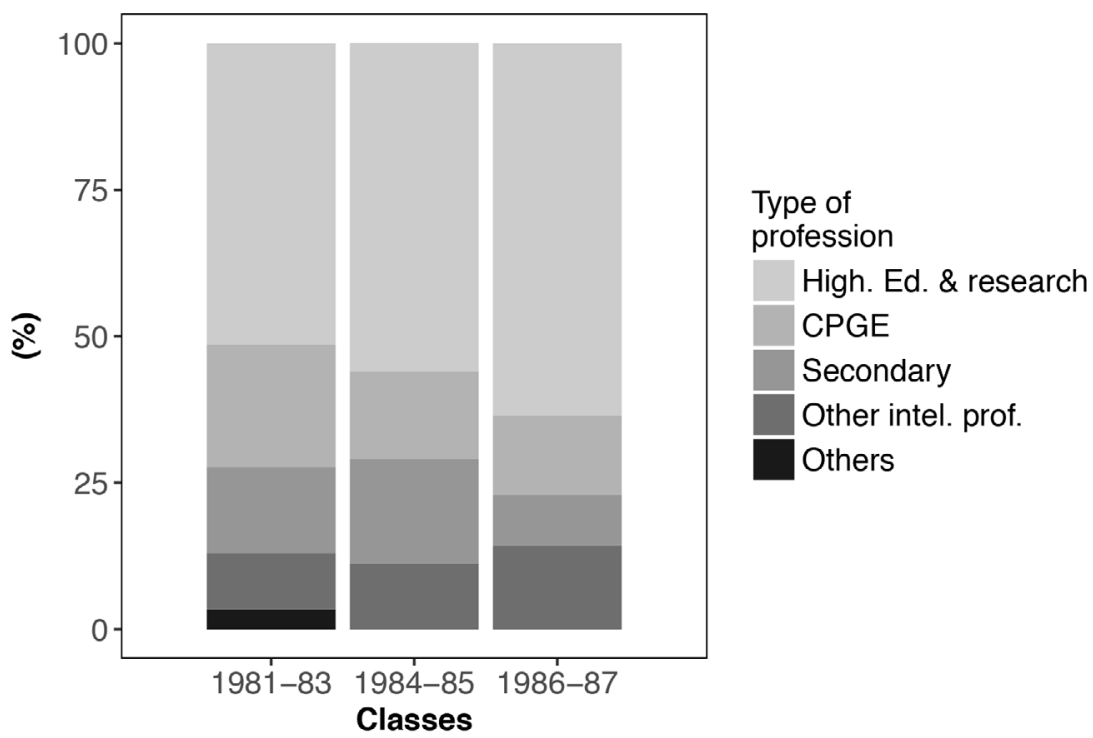

As can be seen, $8 \%$ of students who graduated between 1986 and 1987 were secondary school teachers at the time of the survey. 
La tendance la plus nette est ici l'augmentation de 15 points entre les premières promotions (1981-1983) et les dernières promotions étudiées (1986-1987) des élèves ayant fait carrière dans l'enseignement supérieur et la recherche. Cette tendance s'inscrit dans la continuité de l'alignement progressif des anciennes ENS primaires de Fontenay et surtout de SaintCloud sur les missions de formation des ENS d'Ulm-Sèvres depuis le début des années 1960 (Barbé \& Luc 1982 ; Oulhiou 1981). Elle s'explique également, d'une part, par la création, en lien avec les politiques de démocratisation de l'accès au baccalauréat depuis les années 1980, de nombreux postes dans le supérieur, et d'autre part, par le déclin corrélatif du prestige de l'enseignement en lycée (Bataille 2014).

Le pendant nécessaire à cette orientation accrue vers le doctorat et la carrière académique est une relative désaffection pour les carrières en collège et en lycée. Cette tendance s'observe surtout pour les promotions de la deuxième moitié des années 1980. II faut peut-être voir également dans cette chute marquée de la proportion des anciens élèves enseignants en lycée, un des effets de la réorientation plus nette des priorités des ENS vers la recherche, avec le déménagement à Lyon des sections scientifiques en 1986 (Bataille 2014). On peut d'ailleurs remarquer que la proportion d'enseignants en CPGE décroît elle aussi sur la période,

quoique dans une moindre mesure.

Une troisième tendance est également sensible ici : la légère augmentation en fin de période de la proportion d'élèves occupant une profession intellectuelle supérieure hors enseignement et recherche. Alors que ce type de carrière
The clearest trend here is the fifteen-point increase in students with a career in higher education and research from the first years of graduation studied (1981-83) to the last (1986-87). This trend is in keeping with the gradual alignment since the beginning of the 1960s of the former primary ENS of Fontenay and, in particular, Saint-Cloud with the training programmes of the ENS d'Ulm-Sèvres (Barbé \& Luc 1982; Oulhiou 1981). It can also be explained on the one hand by the creation of numerous positions in higher education, linked to policies of democratisation of access to the baccalauréat since the 1980s, and on the other hand by the consequential fall in prestige of secondary school teaching (Bataille 2014).

The natural counterpart to this increased orientation towards doing a $\mathrm{PhD}$ and following a career in academia is a relative disaffection with careers in schools and colleges. This trend is seen especially in those graduating from the second half of the second half of the 1980s. This distinct drop in the proportion of former students teaching in high schools can perhaps also be seen as one of the effects of the clearer reorientation of ENS priorities towards research, which was behind the transfer of the scientific sections to Lyon in 1986 (Bataille 2014). We note at the same time that the proportion of CPGE teachers also diminished during the period, although to a lesser extent.

A third trend is also significant here: the slight rise (+5\%) at the end of the period in the proportion of students occupied in a higher intellectual position outside education and research. While this type of career was scarcely followed by former cloutiers (nickname for ENS Saint-Cloud students-Barbé \& 
n'était quasiment jamais emprunté à la fin des années 1970 par les anciens « cloutiers » (surnom des élèves de l'ENS de Saint-Cloud - Barbé \& Luc 1982), il concerne presque $15 \%$ des élèves des promotions 1986-1987.

Alors qu'ils étaient les maîtres étalons de l'enseignement en lycée au cours de la première moitié $\mathrm{du} \mathrm{xx}^{\mathrm{e}}$ siècle (Verneuil 2005), les normaliens agrégés professeurs dans le secondaire semblent devenir une espèce très rare potentiellement en voie de disparition. Si l'on peut considérer la carrière dans le secondaire comme plus ordinaire que celle d'universitaire ou de cadre d'une grande multinationale du point de vue de la population française dans son ensemble, il faut ainsi souligner que ce devenir professionnel particulier est relativement exceptionnel au sein de notre échantillon. C'est très précisément cette tension qui informe les vécus de nos enquêtés, comme nous le verrons.

\subsection{Un devenir professionnel qui reste localisé socialement}

Une fois esquissée la position occupée par les carrières enseignantes au sein de l'espace des carrières normaliennes, il s'agit de situer les élèves ayant emprunté de tels itinéraires professionnels vis-à-vis de leurs camarades de promotion. Dans le tableau 2, différentes variables sont mobilisées pour tenter de cerner leur profil sociologique (sexe, origine sociale, niveau de diplôme, première position professionnelle à la sortie de l'ENS). L'origine sociale des élèves est saisie grâce à un indicateur générationnel d'appartenance aux fractions supérieures de l'espace social national, utilisé à
Luc 1982) at the end of the 1970s, it is the path chosen by almost $15 \%$ of those who graduated between 1986 and 1987.

From being the standard masters of secondary school teaching during the first half of the 20th century (Verneuil 2005), normaliens agregés seem to be becoming a very rareand potentially endangered-species in secondary schools. As a career in secondary education may be considered to be more ordinary, from the point of view of the French population as a whole, than that of an academic or manager of a large multinational, it must thereby be emphasized that this particular choice of occupation is relatively rare within our sample. It is precisely this tension which informs our respondents' experiences, as we will see.

\subsection{A career option that remains socially rooted}

Having outlined the position that teaching holds within the sphere of normalien careers, we must situate those students who have followed such a professional route vis-a-vis their peers of the same academic year. In table 2 , different variables are employed to try to identify the sociological profile of former students (gender, social origin, level of academic qualifications, first professional role after ENS). Students' social origin is determined using a generational indicator of class status within the national social space which has frequently been used in research using similar populations (Ferrand, Imbert, Marry 
plusieurs reprises dans des recherches sur des populations similaires (Ferrand, Imbert, Marry 1999 ; Le Bras 1983), et dont la construction mérite d'être explicitée. Cet indicateur permet d'identifier quatre types de configurations familiales particulières : les familles « fortement dotées » dans lesquelles on repère au moins un parent et un grand-parent ayant exercé une profession intellectuelle supérieure ; les familles « en ascension » dans lesquelles un des parents mais aucun grand-parent n'exerçait ce type de profession ; les familles «peu dotées » dans lesquelles aucun ascendant n'a occupé une telle profession ; et enfin, les familles « en rattrapage » dans lesquelles c'était le cas d'un grand-parent mais d'aucun des parents. Cette dernière catégorie, disparate et représentant une proportion très réduite de l'échantillon, a été écartée des analyses présentées ici - ce qui explique que la somme des pourcentages concernant la typologie familiale soit différente de $100 \%$
1999; Le Bras 1983) - the construction of which deserves clarification. This indicator allows us to identify four specific types of family configuration: "well-off" families, in which at least one parent and grandparent have been employed in a higher intellectual occupation; "upwardly mobile" families, in which one parent but no grandparent has been employed in such an occupation; "underprivileged" families, in which nobody in the family has held such an occupation; and, finally, those who are "catching up": wherein a grandparent was employed in such an occupation but neither parent has been. This last category, which is disparate and represents a very reduced proportion of the sample, has been ruled out of the analysis presented here-which explains why the sum of the percentages concerning family typology does not equal $100 \%$. 
Tableau 2. Profils sociaux et scolaires des élèves en fonction de leur destination professionnelle (en \% colonne)

\begin{tabular}{|c|c|c|c|c|c|c|c|}
\hline & & PU ou DR & $\begin{array}{l}\text { MCF, CR ou } \\
\text { PRAG }\end{array}$ & CPGE & Secondaire & Autre prof. & Ensemble \\
\hline \multirow[t]{2}{*}{ Sexe } & Femme & 21 & 53 & 44 & 65 & 37 & 44 \\
\hline & Homme & 79 & 47 & 56 & 35 & 63 & 56 \\
\hline \multirow[t]{3}{*}{ Or. sociale } & Faib. Dot. & 21 & 28 & 38 & 40 & 12 & 28 \\
\hline & Ascension & 31 & 32 & 31 & 26 & 22 & 30 \\
\hline & Fort. Dot. & 40 & 32 & 24 & 25 & 59 & 34 \\
\hline \multirow{3}{*}{ Concours de l' } & Agrégation & 88 & 94 & 97 & 88 & 61 & 88 \\
\hline & CAPES & 1 & 1 & 2 & 12 & 4 & 3 \\
\hline & Aucun & 11 & 5 & & & 35 & 9 \\
\hline \multirow[t]{2}{*}{ Niv. diplôme } & $<\mathrm{Bac}+5$ & 3 & 11 & 64 & 89 & 65 & 36 \\
\hline & $>\mathrm{Bac}+5$ & 97 & 89 & 36 & 11 & 35 & 64 \\
\hline \multicolumn{2}{|c|}{ Premier emploEns. Sup." } & 88 & 82 & 31 & 11 & 44 & 60 \\
\hline & Ens. Sec. & 10 & 17 & 69 & 84 & 17 & 34 \\
\hline & Autre & 2 & 2 & 0 & 5 & 40 & 6 \\
\hline \multicolumn{2}{|l|}{ Total (N) } & 96 & 137 & 72 & 57 & 49 & 100 \\
\hline
\end{tabular}

Lecture : $40 \%$ des anciens élèves interrogés devenus enseignants dans le secondaire sont issus de familles peu dotées en capitaux symboliques et économiques.

: Cette catégorie concerne notamment les expériences en tant qu'Ancien Normalien

Doctorant [AND] ou Assistant Moniteur Normalien [AMN]

Le sous-groupe des enseignants du secondaire se singularise en premier lieu par une forte féminisation $(65 \%$ de femmes contre $21 \%$ chez les PU ou DR et $53 \%$ chez les MCF ou $\mathrm{CR})$. Comme nous le verrons de manière plus approfondie par la suite, le taux important de femmes qui se retrouvent dans ce type de carrière professionnelle renvoie en partie à certaines représentations genrées du métier d'enseignante du secondaire qui serait « bien pour une femme » (Cacouault-
Table 2. Social and academic profiles of students according to career outcome (\%)

\begin{tabular}{|c|c|c|c|c|c|c|c|}
\hline & & P or RD & L, R or PRAG & CPGE & Sec & Oth. Int. Occ. & Total \\
\hline \multirow[t]{2}{*}{ Sex } & Female & 21 & 53 & 44 & 65 & 37 & 44 \\
\hline & Male & 79 & 47 & 56 & 35 & 63 & 56 \\
\hline \multirow[t]{3}{*}{ Soc. Origin } & Underprivileged & 21 & 28 & 38 & 40 & 12 & 28 \\
\hline & Upwardly mobile & 31 & 32 & 31 & 26 & 22 & 30 \\
\hline & Well off & 40 & 32 & 24 & 25 & 59 & 34 \\
\hline \multirow{3}{*}{$\begin{array}{l}\text { Teaching entry } \\
\text { exam }\end{array}$} & Agrégation & 88 & 94 & 97 & 88 & 61 & 88 \\
\hline & CAPES & 1 & 1 & 2 & 12 & 4 & 3 \\
\hline & None & 11 & 5 & - & - & 35 & 9 \\
\hline \multirow[t]{2}{*}{$\begin{array}{l}\text { Qualification } \\
\text { level }\end{array}$} & $\begin{array}{l}\text { <Masters or } \\
\text { equivalent }\end{array}$ & 3 & 11 & 64 & 89 & 65 & 36 \\
\hline & $\begin{array}{l}\text { >Masters or } \\
\text { equivalent }\end{array}$ & 97 & 89 & 36 & 11 & 35 & 64 \\
\hline \multirow[t]{3}{*}{$\begin{array}{l}\text { First job after } \\
\text { leaving ENS }\end{array}$} & $\begin{array}{l}\text { Higher teaching } \\
\text { position }^{*}\end{array}$ & 88 & 82 & 31 & 11 & 44 & 60 \\
\hline & Sec. teacher & 10 & 17 & 69 & 84 & 17 & 34 \\
\hline & Other & 2 & 2 & 0 & 5 & 40 & 6 \\
\hline Total (N) & & 96 & 137 & 72 & 57 & 49 & 100 \\
\hline
\end{tabular}

As can be seen, $40 \%$ of former students questioned who had become as secondary schoo teachers were from underprivileged families in terms of symbolic and economic capital. *: This category particularly concerns experiences as a Ancien Normalien Doctorant [AND] or an Assistant Moniteur Normalien [AMN]

The sub-set of secondary teachers stands out first of all for its high number of female members (65\% women, compared with $21 \%$ of Ps or RDs, and $53 \%$ of Ls or Rs). As we will see next in more detail, the large percentage of women who follow such a professional career is partly linked to gendered representations of the secondary education teaching profession as being "suited to women" (Cacouault-Bitaud 2007), since it would enable them to follow the occupational 
Bitaud 2007), en ce qu'il permettrait plus facilement de suivre un potentiel conjoint lors de ses mobilités professionnelles par rapport aux carrières dans l'enseignement supérieur.

Sous l'angle du type de configuration familiale d'origine, les enseignants en collège et lycée se caractérisent également par une forte proportion d'anciens élèves issus de familles peu dotées. Cette surreprésentation d'élèves issus de milieux sociaux plus modestes dans les carrières enseignantes traduit les difficultés à transformer un capital scolaire en ressources professionnelles effectives pour les élèves en ascension sociale, comme cela a été souligné dans le cas des écoles de commerce les plus prestigieuses (Lambert 2010). Mais, comme nous le verrons par la suite, de tels parcours sont également informés par des stratégies d'ascension sociale par l'école spécifiques aux anciens élèves issus de familles

populaires.

Concernant la réussite à un concours de l'enseignement, les normaliens enseignants du secondaire ne se distinguent pas nécessairement par un taux d'agrégés plus élevé que ceux et celles ayant embrassé une carrière académique. Pour les générations des années 1980, c'est le double cursus agrégation/thèse qui semble avoir été la norme. Cette tendance s'est largement infléchie dans les générations plus récentes, où la préparation au concours de l'agrégation est moins courante chez ceux et celles qui se destinent à des carrières universitaires, en particulier chez les scientifiques

(Cour des comptes 2012). moves of a potential spouse more easily than a career in higher education.

From the angle of original family configuration type, secondary teachers are equally characterized by a high proportion of former students from underprivileged families. This overrepresentation of students from more modest social backgrounds in teaching careers is a sign of the difficulties involved in converting academic capital into effective professional resources for students who are socially upwardly mobile, as has been highlighted by the case of the most prestigious business schools (Lambert 2010). But, as we will see, such career choices are also informed by strategiesspecific to former students from working-class families-of social ascent via schooling.

Regarding success in a competitive teaching exam, normalien secondary school teachers do not necessarily stand out for having a higher rate of agrégés (the name given to those who have passed the agrégation) than among those who have chosen an academic career. For the generations of the 1980s, a double qualification of agrégation/PhD appears to have been the norm. This trend has largely reversed in more recent generations, for whom preparation for the agrégation contest is less common among those who intend to follow academic careers, in particular among science students (Cour des comptes 2012). 
Enfin, les deux derniers tris croisés présentés dans le tableau 2, concernant la composition des différents sousgroupes d'élèves en fonction du niveau de diplôme et du type de premier emploi occupé, permettent de mettre une touche finale au portrait rapidement brossé ici. Ils montrent que la proportion d'anciens élèves docteurs travaillant dans le secondaire est relativement basse. Cette observation semble indiquer que le processus d'orientation durable vers le secondaire intervient tôt dans le parcours postENS - et que le nombre de cas d'anciens élèves qui se tournent vers le secondaire après avoir soutenu une thèse et échoué à trouver un poste dans le supérieur, souvent mis en avant dans les médias, est en réalité minoritaire. Cette impression est renforcée par l'analyse de la première position professionnelle à la sortie de l'ENS. $84 \%$ de nos enquêtés en poste en lycée ou en collège au moment de l'enquête ont commencé leur carrière dans le secondaire. Dans le même ordre d'idée, ceux et celles qui ont réussi à décrocher un contrat d'AND ou d'AMN ont bien souvent continué sur la voie de la carrière académique et sont rarement retournés enseigner durablement dans le secondaire.

Les carrières des anciens normaliens s'engageant à long terme sur la voie de l'enseignement secondaire semblent donc le fruit d'une bifurcation relativement précoce après I'ENS, concernent une faible proportion d'élèves, et en particulier des femmes et/ou des élèves issus de milieux sociaux modestes. Si cet aperçu quantitatif permet de dresser quelques traits saillants, il passe néanmoins sous silence les importantes variations de vécu et d'appropriation de cette expérience particulière qui se font jour dans les entretiens, comme nous allons le voir à présent.
In fact, the last two cross tabulations presented in table 2 concerning the composition of different sub-categories of student according to level of qualification and type of first employment held, allow us to add the final touches to the portrait we have quickly painted here. They show that the proportion of former PhD students working in secondary education is relatively low. This observation seems to indicate that the process of long-term orientation towards secondary education occurs early on in the journey post-ENS - and that the number of cases of former students who turn to secondary education having completed a thesis and failed to find a position in higher education, which is often highlighted in the media, is in reality minimal. This impression is reinforced by analysis of graduates' first professional role after leaving ENS. Of the respondents in school or college teaching positions at the time of the survey, $84 \%$ began their career in secondary education. Similarly, those who have been successful in gaining an AND or AMN contract have very often continued along the academic career route and rarely return to teach in secondary education long term.

The careers of former normaliens who commit to secondary education long term therefore appear to be the result of a bifurcation relatively soon after ENS, and concern a small proportion of students, in particular women and/or students from modest social backgrounds. While this quantitative overview addresses several salient points, it says nothing about the significant variations in how this specific experience is lived and adopted, which is something that emerges in the interviews, as we will now see. 


\section{Le « ratage » comme construction collective}

\subsection{Un moment de rupture}

II faut tout d'abord souligner que malgré la pluralité des expériences, l'engagement durable dans le secondaire est généralement présenté comme un accident de parcours par nos enquêtés. On peut repérer d'importantes variations sur ce point en fonction des promotions, les enquêtés ayant intégré l'ENS dans la première moitié des années 1980 étant plus nuancés. Mais, même si « obliquer » (Benoît, S, PU, Paris, Fam-) vers le secondaire était une éventualité pour nombre de nos enquêtés, c'était - la plupart du temps - uniquement sous la forme d'un " purgatoire » (Marie, L, CPGE, Prov, Fam-), en attendant d'avoir fini leur thèse et d'être recrutés à

l'université, voire en CPGE.

Les récits des premières expériences d'enseignement dans le secondaire peuvent ainsi prendre un accent relativement dramatique, comme dans le cas de Louis (L, CPGE, Paris, Fam+), agrégé de philosophie, enseignant en CPGE dans la région parisienne au moment de l'entretien. Suite à l'échec de sa candidature pour un poste d'AMN, il a pris un poste dans le secondaire le temps de commencer une thèse. Selon lui, « le choc de l'enseignement secondaire » a été tel qu'il a rapidement abandonné toute velléité de poursuivre un travail

doctoral.

« J'ai été nommé dans un lycée technique... Mon premier poste, c'était un lycée technique. Je ne savais même pas que c'était possible, en étant normalien et agrégé, d'être nommé dans un lycée technique. J'étais sans doute... Bien

\section{2. "Failure" as a collective construction}

\subsection{A moment of rupture}

We must first of all point out that despite the plurality of experiences, long-term commitment to secondary education is generally presented as an accident in the career paths of our respondents. We can identify significant variations on this point depending on academic year, with those respondents who began ENS in the first half of the 1980s being the more nuanced. But, even though "veering off" (Benoît, S, P, Paris, Fam-) towards secondary teaching was a possibility for many of our respondents, it was-most of the time-solely in the form of a sort of "purgatory" (Marie, A, CPGE, Prov, Fam-), while they waited to finish their thesis and be appointed at a university, or at least to teach CPGE.

The accounts of the first secondary school teaching experiences can thereby take on a relatively dramatic aspect, as in the case of Louis (A, CPGE, Paris, Fam+), agrégé in philosophy, who is teaching CPGE in the Paris region at the time of the interview. After failing to gain a position as an $A M N$, he took a position in secondary education at the same time as beginning a thesis. He says that the "shock of secondary teaching" was so great that he quickly abandoned any attempt to pursue a PhD.

"I was appointed to a technical college... My first job was a technical college. I didn't even know that that was possible, to be a normalien and agrégé and be appointed to a technical college. I must've been... I was obviously misinformed. How 
évidemment, j'étais mal renseigné. Comment dire... Je pensais que ça allait de soi, puisque j'avais fait Normale sup' et l'agreg', qu'on me donnerait forcément une classe littéraire. Ça allait de soi. Bon, premier poste en lycée technique... Je l'ai très, très mal vécu. Comme une insulte. Je me suis senti insulté par l'institution. »

Les causes de ce type d'entrée tumultueuse dans le métier sont multiples : différence entre le niveau de sélection du concours d'entrée et le contenu des enseignements à assurer en lycée (et surtout en collège), éloignement géographique forcé, manque de formation proprement pédagogique durant les années à l'École. Le décalage est d'autant plus durement ressenti que la discipline de spécialité est réputée prestigieuse dans l'espace académique, comme c'est le cas de la philosophie et des mathématiques (Bourdieu 1984). Indice du caractère parfois traumatique - et peu anticipé que peuvent avoir pris ces premières expériences, les métaphores guerrières (« J'ai fait mon Vietnam », « Je suis allé au feu ») abondent dans les récits des enquêtés, d'autant plus quand les premières années d'enseignement se sont déroulées dans des établissements relativement défavorisés. On verra par la suite que l'amplitude du « choc » ressenti à l'arrivée dans le secondaire est particulièrement forte dans le cas - rare, comme on l'a vu plus haut - des élèves issus de familles « fortement dotées ».

Néanmoins, l'entrée et le maintien dans une carrière d'enseignants en lycée ou en collège n'ont pas toujours été vécus comme une « insulte ». Alexia (L, Autre -, Prov, Fam $\uparrow)$, qui a été enseignante de langue en collège/lycée pendant to explain that... I thought it was self-evident, since l'd been to ENS and I was agrégé - of course l'd be given a teaching position in a high school art department. It was a done deal. But yeah, first job at a technical college... I took it really badly. Like an insult. I felt insulted by the institution."

The causes behind this kind of tumultuous entry into the profession are multiple: for example, the difference between the level of selection in the agrégation and the content of the lessons to give at high school (and even more so at secondary school); enforced geographical distance; and the lack of real pedagogical training during the ENS years. The disparity is felt all the more strongly when a graduate's specialized discipline has a prestigious reputation within the academic sphere, as is the case for philosophy and mathematics (Bourdieu 1988). In a sign of the sometimes traumatic, and scarcely anticipated, nature of the experience, metaphors of war abound in respondents' accounts - "I did my Vietnam," "I was sent to the front lines"-and even more so when the first years of teaching took place at relatively disadvantaged establishments. Next, we will see that the level of "shock" felt on arrival in secondary teaching is particularly strong in the cases of students from "well-off" families, which are rare as we have seen above.

However, entry into and continuation of a career in secondary teaching is not always experienced as an "insult." Alexia ( $A$ Other-, Prov, Fam $\uparrow$ ), for example, who has been a school language teacher for twenty years, criticizes her classmates 
une vingtaine d'année, fustige par exemple ses camarades qui cherchaient à fuir l'enseignement à tout prix («Oui, d'accord, tout le monde avait peur de faire de l'enseignement. Mais on était là pour ça quand même. Voilà. "). Du fait de cette disposition relativement favorable pour l'enseignement, Alexia a beaucoup mieux vécu ses premières années d'enseignement dans un établissement d'une commune rurale de l'Est de la France - « le lycée de province, moi, j'en venais, donc je me retrouvais dans mes meubles »-d'autant plus qu'elle était nommée dans un « lycée sympa » proche de celui où travaillait son compagnon ("c'était confortable »). Elle admet toutefois que cette orientation de carrière n'a pas été évidente au début et qu'il lui a fallu «quelques années [pour] enterrer [ses] rêves universitaires, [ses] rêves de grandeur ».

Aussi, même quand la possibilité de devenir enseignant était largement intégrée a priori, l'entrée dans ce type de carrière apparaît rétrospectivement comme un turning point de leur parcours. Cet « embranchement» (Abbott, 2010) a contribué à réduire durablement l'éventail de choix qui s'ouvraient à eux une fois terminées leurs années à l'ENS.

\subsection{Un travail de symbolisation différencié : le poids de l'origine sociale et du genre}

Parmi les différents outils conceptuels disponibles pour appréhender les dynamiques biographiques, le turning point occupe une place à part, en ce qu'il ne peut être désigné comme tel qu'a posteriori - et donc qu'il est nécessairement l'objet de réinterprétation par les personnes concernées who did whatever they could to get out of teaching ("Yes, ok, everyone was scared of teaching. But that was what we were there for, wasn't it. Well there you go"). This relatively favourable disposition towards teaching meant Alexia had a much better experience of the first years of teaching at an establishment in a rural area in the east of France- "l'd gone to a provincial school myself, so I felt at home"-even more so since she was appointed at a "nice school" near the one where her partner worked ("it was comfortable"). She admits, however, that this career direction was not always what she had had in mind, and that it took "a few years to bury [her] dreams of academia and greatness."

Also, even when the possibility of becoming a teacher was to a large extent accepted a priori, entry into this type of occupation appears in retrospect as a turning point in the respondent's career path. This "junction" (Abbott 1997) helps to significantly reduce the range of choice available to them after the ENS years are over.

\subsection{Work of differentiated symbolisation: the role of social origin and gender}

Among the various tools available to help understand biographical dynamics, the turning point is unique in that it can only be defined as such a posteriori-and hence it is necessarily an object of reinterpretation for those concerned (Bidart, Longo, Mendez 2013). This intrinsic "narrativity" of 
(Bidart, Longo, Mendez 2013). Cette «narrativité » intrinsèque du turning point (Abbott, 2010) peut rendre l'interprétation de tels événements extrêmement délicate. En mettant en regard la mise en récit de ces moments de rupture et les parcours dont cette mise en récit est en partie le produit, on peut néanmoins interpréter sociologiquement le ton donné à ces événements dans les récits de vie analysés (Demazière

2007).

Dans le cas de nos enquêtés, même si la bifurcation durable vers l'enseignement secondaire est souvent présentée comme un fait marquant, la puissance du sentiment de relégation associé à cet événement varie par exemple très fortement en fonction de leur parcours scolaire et social antérieur à l'intégration de l'ENS

Pour les anciens élèves issus de milieux populaires notamment, l'accès à une position d'enseignants en lycée est moins souvent présenté comme une rupture que comme la consolidation d'une ascension sociale entamée durant la scolarité secondaire et consacrée par l'intégration d'une CPGE puis d'une grande école. En ce sens, l'accès à une fonction enseignante a pu constituer une " sortie honorable et raisonnable » à des mobilités sociales ascendantes de forte amplitude (Hugrée 2010) - comme dans le cas des enfants de la deuxième démocratisation scolaire s'engageant sur la voie du CAPES (certificat d'aptitude au professorat du second degré - concours permettant d'enseigner dans le secondaire) the turning point (Abbott 1997) can make the interpretation of such events very difficult. By focusing on the way these moments of rupture are put into a narrative, and on the trajectories of which this narrative is partly the product, we can nevertheless sociologically interpret the tone given to these events in life stories we analyse (Demazière 2007).

In the case of our respondents, even if a long-term bifurcation to secondary education is often presented as a prominent event, the strength of the feeling of relegation associated with it varies greatly depending, for example, on their academic and social background prior to starting at ENS.

For former students from working-class backgrounds in particular, access to a teaching position in a high school is less often presented as a rupture than as a consolidation of a social ascent begun during their secondary education and further established via their entry into CPGE and then a grande école. In this sense, access to a teaching position constitutes an "honourable and reasonable path" to significant upward social mobility (Hugrée 2010) - such as in the case of students of France's second wave of academic democratisation with regard to the CAPES (Certificat d'Aptitude au Professorat du Second degré-an entrance exam to get into secondary teaching). 
C'est par exemple le cas de Stéphane (L, CPGE, Par, Fam -), aujourd'hui enseignant de lettres en CPGE, après avoir passé la première moitié de sa carrière dans un lycée de la « «banlieue de la banlieue» parisienne ». Premier bachelier de sa lignée, issu d'un milieu très modeste et rural (son père était salarié agricole et sa mère sans emploi), Stéphane dit avoir suivi « un cheminement » qui s'est construit « étape par étape »: suite à une scolarité secondaire exemplaire dans le lycée de sa commune, il intègre la meilleure CPGE possible à proximité. Pour sa dernière année de CPGE, il décide finalement de présenter sa candidature dans une khâgne parisienne et réussit à intégrer l'ENS l'année suivante. La vraie rupture dans son parcours semble avoir été l'intégration d'une ENS où la confrontation avec ses camarades, généralement issus de familles mieux dotées en capitaux économiques et scolaires que la sienne et se vivant comme « l'élite de la nation », a été particulièrement difficile à vivre. Alors que l'ENS représentait pour lui « l'occasion de devenir un prof ", il s'est senti en décalage vis-à-vis de ses camarades qui visaient pour la plupart d'entre eux et elles des postes dans le supérieur. Après avoir décroché l'agrégation et fait un an de Diplôme d'études approfondies [DEA - diplôme préparant l'entrée en thèse] un peu par dépit, il a pris un poste dans un lycée d'une ville ouvrière du nord de l'agglomération parisienne, avant d'être nommé quelques années plus tard en CPGE. Dans les rares cas de très forte ascension sociale, comme celui de Stéphane, la prise de poste durable dans le secondaire n'implique pas nécessairement une bifurcation importante et est donc connotée moins négativement, dans la mesure où elle s'inscrit dans la continuité du parcours d'intégration de l'ENS.
This is, for example, is the case for Stéphane (A, CPGE, Paris, Fam-), who today teaches literature in CPGE after having spent the first half of his career at a high school in the "banlieue of the Parisian banlieue" (the banlieues, or suburbs, denoting the most marginal, disaffected, and arguably neglected parts of French cities). From a very humble, rural background (his father was an agricultural labourer and his mother unemployed), Stéphane was the first in his family to get a degree; he says he has been on a "journey," which has taken place "bit by bit": after an exemplary secondary school education in his home town he entered the best CPGE available nearby. For his last year of CPGE, he decided in the end to apply for a Parisian khâgne (a CPGE dedicated to literature and the humanities), and succeeded in getting into ENS the following year. The real rupture in his career path seems to have been his entry into ENS, where the confrontation with his fellow students-who were generally from families that were better off in terms of economic and academic capital than his and who saw themselves as the "elite of the nation"-was a particularly difficult experience. While for him ENS represented the "opportunity to become a teacher," he felt out of step with his peers, who were for the most part aiming for positions in higher education. After having passed the agrégation and done a year of the Diplôme d'études approfondies [DEA - a diploma which used to prepare students for a $\mathrm{PhD}$, to some extent out of spite he took a position in a school in a working-class town in the north of Paris, before being appointed several years later to teach CPGE. In rare cases of steep social ascent such as Stéphane's, obtaining a long-term position in secondary education does not necessarily imply a major bifurcation, and 


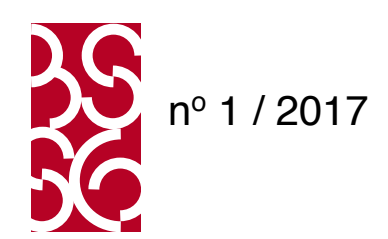

Ce type de discours tranche nettement avec les propos de Louis, rapportés plus haut, pour qui la nomination dans l'enseignement technique a été vécue comme une « insulte ». Pour comprendre la violence exprimée par Louis à propos de cette expérience (« L'horreur absolue... oui à ce point-là »), il faut également la resituer dans la dynamique globale de son parcours. Originaire d'une grande ville de l'Ouest de la France, fils d'un médecin et d'une mère au foyer passionnée de littérature et de cinéma, Louis entre en classe préparatoire sur les conseils d'un oncle énarque - initialement pour intégrer Sciences-Po Paris et devenir « diplomate », même si la question du projet professionnel était encore très vague pour lui. Converti à la philosophie durant ses années de khâgne, il décide de préparer les concours de l'ENS dans l'idée de « continuer à approfondir sa connaissance en philosophie », alors même qu'il avait hérité d'une image "pas très favorable de l'enseignement » par ses condisciples et par son père, pour qui cette voie ne représentait pas « un bon choix » professionnel. Alors que son parcours scolaire a principalement été mû par des principes élitistes (intégrer un cursus sélectif pour échapper aux premiers cycles de l'université) et disciplinaires (satisfaire son goût pour la philosophie, une discipline particulièrement valorisée dans l'espace académique), on comprend dès lors que la bifurcation vers le technique - un des secteurs les moins légitimes du système français d'enseignement - ait pu constituer une rupture importante dans son parcours. II est d'ailleurs significatif que dans les cas semblables à celui therefore has less negative connotations insofar as it is a continuation of the path that led to ENS entry.

This type of discourse contrasts markedly with the words of Louis, quoted earlier, for whom an appointment to a technical college was viewed as an "insult." To understand the intensity of feeling expressed by Louis regarding this experience ("the absolute horror... yes, that bad"), we must reframe it in the wider context of his career path. Louis grew up in a city in the west of France; his father was a doctor and his mother a housewife with a passion for literature and cinema. He began classes préparatoires on the advice of his uncle who was an ENA (National School of Administration) graduate-initially to go to Sciences-Po Paris and become a "diplomat," even if the subject of his career was still very vague for him. Having turned to philosophy during his khâgne years, he decided to prepare for the ENS entry exam with the idea of "continuing to expand his knowledge of philosophy" even though he had inherited a "rather unfavourable" image of teaching from his peers and his father, for whom this route did not represent a "good [professional] choice." Since his academic choices have primarily been driven by principles that were both elitist (getting into a selective curriculum in order to escape the first years of university) and disciplinary (satisfying his taste for philosophy, a particularly highly regarded discipline in the academic sphere), we thereby understand that the bifurcation towards teaching technology-one of the least valued sectors of the French education system-constituted a considerable rupture in his career path. It is also significant that in cases similar to Louis's, whereby getting a place at an ENS is initially part of a family strategy to consolidate a 
de Louis, où l'intégration de l'ENS s'inscrit initialement dans une stratégie familiale de consolidation d'une position sociale dominante, les interactions avec les membres de la famille peuvent amplifier l'assimilation de l'engagement durable dans une carrière enseignante à une relégation. Ainsi Louis relève qu'il s'est vu « reprocher » " après coup » par sa mère de « ne pas être devenu ministre ». Même s'il précise que cette remarque a été formulée « sur un coup de colère » et n'était pas nécessairement « sincère ", ce type de réaction contribue à donner à ce turning point une forte connotation

de ratage.

Le genre imprègne également fortement les interprétations rétrospectives de l'engagement durable sur la voie de l'enseignement secondaire. Pour nombre de nos enquêtées, leur nomination sur un poste en lycée ou en collège s'est souvent accompagnée de l'arrivée d'un premier enfant. Dans de telles situations, la probabilité de raccrocher la voie royale de la thèse et de l'enseignement supérieur a été drastiquement réduite, du fait de la répartition, fréquemment inégale au sein des couples, du travail de care domestique. Pour celles qui avaient des ambitions académiques, l'inscription dans une carrière d'enseignante du secondaire s'est ainsi bien souvent transformée en « plancher collant » (Buscatto \& Marry 2009). Les témoignages semblables à celui de Sandrine $(\mathrm{L}, \mathrm{Sec}$, Paris, Fam $\uparrow$ ), enseignante en langue depuis une quinzaine d'année au moment de l'entretien, sont relativement nombreux. En couple avec un jeune médecin au moment de sa dernière année de scolarité, l'arrivée de leur premier enfant apparaît rétrospectivement clairement corrélée avec l'abandon d'un projet de thèse. position of power in society, interactions with family members can encourage the association of a long-term commitment to a teaching career with relegation. Thus, Louis notes that he was "blamed" "after the fact" by his mother for "not becoming a minister." Although he specifies that this remark was made "in a fit of anger" and that it was not necessarily "sincere," this type of reaction contributes towards the connotation of this turning point with failure.

Gender plays an equally strong role in retrospective interpretations of long-term engagement in secondary education teaching. For many of our female respondents, their appointment to a teaching position in a school or college often corresponded with the arrival of their first child. In such situations, the likelihood of re-joining the royal road of the thesis and higher education teaching is drastically reduced owing to the frequently uneven division of domestic care work between partners. For those who had academic ambitions, embarking on a career in secondary education teaching thus often becomes a "sticky floor" (Buscatto \& Marry 2009). Testimonies like that of Sandrine (A, Sec, Paris, Fam $\uparrow)$, who has been a foreign language teacher for about fifteen years at the time of the interview, are relatively frequent. She was in a relationship with a young doctor during her last year of education, and the arrival of their first child appears retrospectively to be clearly correlated with her abandoning her thesis. 
“ C'est-à-dire que je n'avais pas du tout l'intention d'aller enseigner en lycée ou en collège. Voilà, et je me suis retrouvée en lycée ou en collège. Donc je me suis inscrite en DEA. En me disant... Voilà... Et puis j'ai passé mon DEA. Et puis ça s'est arrêté là parce que j'ai fait des enfants [rires]. »

Sandrine s'occupait en priorité des enfants du couple alors que son mari travaillait beaucoup à lancer son cabinet : la dissymétrie statutaire au sein de son couple ${ }^{9}$ a donc rendu impossible son engagement dans un projet de thèse, même si Sandrine relativise aujourd'hui l'impact de l'arrivée de son premier enfant sur son parcours («ça a été la bonne excuse. Je crois... Je crois que si j'avais vraiment voulu, j'aurais continué. ») et met également en cause un « complexe

d'infériorité intellectuelle».

L'ambivalence qui imprègne les propos de Sandrine est palpable dans nombre d'entretiens avec d'anciennes élèves - même si, dans le cas de certaines comme Claire (S, Sec, Paris, Fam+), enseignante en sciences de la vie et de la terre à Paris, le fait de « devenir prof » en lycée plutôt qu'ingénieure ou universitaire était clairement lié à sa volonté de «fonder une famille ». La souplesse temporelle permise par le métier d'enseignant secondaire aurait ainsi pu permettre à ces femmes de garder un pied dans le parcours académique, si elles n'avaient dû in fine prendre en charge les tâches domestiques ou l'éducation des enfants, surtout

9 Parmi nos enquêtées enseignantes dans le secondaire, $90 \%$ sont en couple avec un compagnon ayant un niveau de diplôme et/ou un statut professionnel égal ou supérieur au leur, alors que c'est le cas de seulement $75 \%$ des hommes.
"I mean I never intended to go and teach in a school or college. And that's what I ended up doing. So I applied to do the DEA. Saying to myself... There you go... And then I got my DEA. And then I stopped there because I had kids [laughs]."

Sandrine looked after the couple's children first and foremost while her husband worked a lot setting up his practice: the asymmetry of status in their relationship ${ }^{9}$ therefore made her commitment to pursuing a thesis impossible, even if today Sandrine plays down the impact of the arrival of her first child on her career ("it was a good excuse. I think... I think that if I'd really wanted to, l'd have continued"), and also blames an "intellectual inferiority complex."

The ambivalence that permeates Sandrine's answers is palpable in a number of interviews with former studentseven when, in the case of some, such as Claire (S, Sec, Paris, Fam+), a science teacher in Paris, becoming a "school teacher" rather than an engineer or academic was clearly linked to a desire to "start a family." The flexibility in terms of working hours that the profession of secondary school teaching facilitates would thus have allowed these women to keep one foot in an academic career, if they had not ultimately had to take care of domestic tasks or their children's education,

9 Of our female respondents teaching in secondary education, $90 \%$ had a partner with qualifications and/or professional status equal to or higher than theirs, while this was the case for only $75 \%$ of male respondents. 
lorsqu'elles étaient en couple avec un compagnon lui aussi fortement diplômé ${ }^{10}$.

Aussi, si elle n'est pas nécessairement présentée comme une relégation, la bifurcation durable vers l'enseignement secondaire semble pour ces enquêtées, située au carrefour de différentes dynamiques « productives » et « reproductives » 11 parfois contradictoires, qui font rétrospectivement apparaître les premières années en poste dans le secondaire comme un

moment critique de leur parcours.

\subsection{Quand le titre se fait stigmate : les interactions avec les collègues et la hiérarchie}

Un dernier facteur peut contribuer à assimiler l'engagement dans une carrière d'enseignants du secondaire à une relégation : les réactions rencontrées dans les interactions avec les collègues et la hiérarchie scolaire.

D'une manière générale, nos enquêtés en poste en lycée ou en collège parlent très peu de leur passé scolaire dans leur entourage professionnel. Pour Xavier (S, Sec, Prov,

10 C'est aussi ce que montrent, dans la lignée des travaux classiques de François de Singly (1987), les enquêtes qualitatives (Jarty 2009) ou quantitatives (Letrait \& Salane 2015) plus directement centrées sur cette question.

11 Nous reprenons ici la distinction classique posée par Danièle Kergoat entre sphères d'activité « productive » et « reproductive », la deuxième renvoyan aux tâches laborieuses mais non reconnues comme telles - et donc non rémunérées - d'entretien de la force productive, et tout particulièrement, le soin aux enfants, au conjoint et aux parents notamment (Galerand \& Kergoat 2008) above all when in a relationship with a partner qualified to the same level ${ }^{10}$.

Also, while it may not necessarily be presented as relegation, long-term bifurcation to secondary education seems for these respondents to be located at the crossroads of the differing, sometimes contradictory, dynamics of "production" and "reproduction"11, making their first years in a position in secondary education appear in retrospect as a critical point in the course of their career.

\subsection{Qualifications with a stigma attached: interactions with colleagues and management}

A final factor that may contribute to a career in secondary education being associated with relegation is reactions encountered in interactions with colleagues and school management.

In general, those we spoke to in teaching positions in schools or colleges say very little about their academic past to their professional entourage. Xavier (S, Sec, Prov, Fam+), a maths teacher at a high school in the south of the Paris region, rarely states his academic title other than on his CV, above all to

10 In keeping with the classic work of François de Singly (1996), this is also shown in qualitative (Jarty 2009) and quantitative (Letrait \& Salane 2015) surveys that are more directly focused on this issue.

11 Here we are using the classic distinction proposed by Danièle Kergoa between "productive" and "reproductive" spheres of activity: the latter referring to labour tasks which are not recognized as such — and hence are unpaid - of maintenance of productive strength, especially caring for children, a spouse, and in particular parents (Galerand \& Kergoat 2008) 
Fam+), enseignant en mathématiques dans un lycée du sud de la région parisienne, c'est d'abord pour ne pas paraître " cuistre » auprès de ses collègues qu'il affiche très rarement son titre ailleurs que sur son CV. "C'est comme son rang à l'agrégation », « ce sont des choses dont on ne parle pas trop » conclut-il.

Afficher ostensiblement un tel titre dans le but d'obtenir un traitement de faveur contreviendrait, tout d'abord, à l'égalité de traitement a priori garantie par la fonction publique à ses agents d'un rang équivalent. Comme le souligne Xavier sur le ton de l'humour, « ça ne se dit pas "bonjour monsieur l'inspecteur, je suis normalien, vous comprendrez bien que vous ne pouvez quand même pas me considérer comme un prof normal" ". Pour nos enquêtés, la seule catégorie administrative légitime pour faire valoir leurs droits est celle du concours obtenu (« agrégé » ou « capésien »). L'étiquette « d'agrégé » supplante d'ailleurs bien souvent celle " d'élève de l'ENS » dans les relations avec les collègues et l'administration. C'est en effet de cette distinction que dépendent notamment le nombre d'heures de service et la progression salariale.

Néanmoins, d'autres enquêtés rapportent que leur discrétion quant à leur passage par l'ENS, est liée à la crainte d'une mauvaise compréhension de leur parcours par leurs collègues (enseignants ou proviseurs) ou par certains membres de l'administration (en particulier l'inspection pédagogique). Le titre de normalien peut, dans ces circonstances, se transformer en véritable stigmate (Goffman, 1975), c'est-à-dire en attribut pouvant servir de support à une réduction de la personnalité avoid looking arrogant to his colleagues. "It's like your ranking in the agrégation," "we don't talk about things like that much," he concludes.

Flaunting this type of accolade with the intention of receiving favourable treatment would first of all contravene the equal treatment guaranteed a priori to all public servants of the same rank. As Xavier makes the point with humour, "You can't say 'Hello Mr. Inspector, I'm a normalien, you can't treat me like a normal teacher, you know'." For our respondents, the only legitimate administrative category through which to assert their rights is the type of teaching qualification they hold (agrégé, or capésien for the CAPES). The agrégé label very often replaces that of "ENS student" in relations with schools and their administration. Working hours and salary progression among other things effectively depend on this distinction

Other respondents, however, state that their discretion regarding the fact that they attended ENS is linked to a fear of their colleagues (both teachers and management) or members of the administration such as school inspectors in particular not understanding their academic route. The title of normalien can become a stigma (Goffman 1963) in these circumstances, in that it is an attribute that can serve to support the reduction of an individual's personality to caricatured traits. 
à quelques traits caricaturaux. Ce stigmate normalien se décline en deux facettes principales - celle du privilégié qui a mangé son pain blanc, et celle du normalien employé en dessous de ses moyens - qui font de la bifurcation vers le secondaire, une sorte de déchéance.

Pour Émilie, enseignante de lettres dans le nord de la région parisienne (L, Sec, Prov, Fam-), les réactions négatives de certains collègues lorsqu'ils apprennent qu'elle a fait l'ENS viennent en partie du fait qu'ils croient « qu'il y a beaucoup de choses qui leur sont facilitées [sur le plan de la carrière] et que ce n'est pas forcément justifié ». Ce type de ressenti semble être très variable selon le contexte, comme le montre notamment le cas de Louis (L, CPGE, Paris, Fam+). Le premier proviseur qu'il a rencontré avait, selon lui, " des comptes à régler » avec « les agrégés » - et de surcroît les normaliens. II lui aurait déclaré lors de leur première rencontre « vous êtes agrégé, normalien, je n'en ai rien à faire, ce n'est pas ça qui compte à mes yeux ». Cette situation l'a de fait mal disposé à l'égard de cette carrière non désirée à l'origine, ce qui a participé au désarroi de Louis dans un premier temps. Au contraire, le proviseur du lycée dans lequel il enseigne au moment de l'entretien, qui a lui-même fait une CPGE et a la réputation d'être «favorable » au système des CPGE/ Grandes écoles, verserait plutôt dans le cliché inverse de la valorisation un peu « caricaturale » du cursus de Louis - en le citant souvent en exemple lors des conseils de classe par

exemple.
There are two main aspects to the normalien stigma: firstly privilege, in that he or she has had it easy; and secondly being employed in a job for which he or she is overqualified. These aspects turn the bifurcation to secondary education into a form of degradation.

For Émilie, a literature teacher in the north of the Paris region ( $A, \operatorname{Sec}$, Prov, Fam-), the negative reactions of some colleagues when they learn that she has been to ENS partly come from the fact that they believe "that there are many things that are made easier for them [in terms of career], and that this isn't necessarily right." This type of feeling seems to vary a good deal depending on the context, as is well illustrated by Louis's case (A, CPGE, Paris, Fam+). The first head teacher he encountered had an "axe to grind," according to him, when it came to agrégés-especially normaliens. He apparently said at their first meeting "You are agrégé, a normalien, this means nothing to me, it's not what counts in my book." This situation effectively made Louis poorly disposed towards this career he had not wanted in the first place, contributing towards his initial distress. In contrast, the head of the school in which he was teaching at the time of the interview, who has himself done CPGE and is known to be "favourable" towards the CPGE/ Grandes écoles system, would more easily fit the opposite stereotype of somewhat exaggerating the merits of Louis's career path-frequently citing him as an example at staff meetings, for example. 
Cette situation relativement exceptionnelle peut également être source de malentendus avec leur hiérarchie directe, comme ce fut le cas d'Alexia (L, Autre-, Prov, Fam $\uparrow$ ). Comme évoqué plus haut, Alexia - qui a intégré l'ENS dans l'objectif principal de « devenir prof »-compte parmi nos enquêtés les mieux disposés à embrasser ce type de carrière. Ses échanges avec l'inspecteur pédagogique régional, lors de sa première inspection, lui ont toutefois donné le sentiment que le poste qu'elle occupait était « en-dessous » de ses capacités, opérant ainsi une sorte de rappel à l'ordre symbolique.

« C'est-à-dire que le premier inspecteur que j'ai vu, la première... la deuxième année que j'étais au lycée, il m'a annoncé tout de go qu'il avait lu mon dossier administratif, mon parcours universitaire. II m'a dit qu'il voyait bien que je ne voulais pas rester là. [...] II déduisait du fait qu'effectivement j'avais enseigné deux ans en faculté, que j'étais normalienne, que ci, que ça, que j'étais pas à ma place dans ce lycée provincial. Et que donc, je n'allais pas y rester, [...], que j'étais là sans le vouloir. Ce n'était absolument pas mon idée. [...]. Ce n'était pas "vous venez de là, donc forcément, c'est en dessous de vos...". Moi, je n'ai jamais du tout pris ce poste comme étant en dessous de moi. Au contraire, j'étais super bien. J'étais très contente d'être là. »

Si elle n'est pas majoritaire, l'expérience d'Alexia permet d'illustrer comment l'assimilation du turning point de l'engagement durable dans une carrière enseignante à un « ratage » n'est pas réductible à une appréciation individuelle. Elle est le fruit d'un travail collectif de construction du sens (auquel prennent part la famille et les proches comme nous l'avons vu, mais également les collègues et les autres acteurs de l'environnement professionnel).
This relatively unique situation can also lead to misunderstandings with teachers' direct superiors, as was the case for Alexia (A, Other-, Prov, Fam $\uparrow$ ). As mentioned earlier, Alexia-whose main aim in getting into ENS was to "become a teacher"-was one of the most prepared among our respondents to embrace this type of career. However, her exchanges with the regional education inspector during her first inspection gave her the impression that the position she held was "below" her capabilities, thus acting as a kind of reminder of the symbolic order.

"I mean that the first inspector I saw, the first... the second year I was at the school, he told me straight away that he'd read my administrative file, my academic qualifications. He told me he could see I didn't want to stay there... He deduced from the fact l'd taught two years at a university, that I was a normalienne, etc, that I didn't belong in a provincial high school. And that I was therefore not going to stay... that I didn't want to be there. This was definitely not what I thought... It wasn't a case of 'You come from there, so this is definitely below your...' l'd never seen this job as being below me. Quite the opposite, I was really happy. I really liked being there."

While not the experience of the majority, Alexia's case illustrates that interpreting the "turning point" of a long-term commitment to teaching by analogy with "failure" cannot be reduced to individual assessment. Rather, it is the result of a collective construction of meaning (to which family and other relations contribute, as we have seen, but colleagues and other actors of the professional environment also play a part). 


\section{Progression, « refus de parvenir », recherche d'une meilleure «qualité de vie»: trois types de parcours post-bifurcation}

Dans cette dernière partie, nous nous focaliserons sur les différentes manières qu'ont les anciens élèves de s'approprier cette rupture sur le long terme. Les trois types de parcours décrits ci-dessous ne sont pas propres aux élèves des ENS - et pourraient, à notre sens, s'appliquer aux autres enseignants du secondaire. Néanmoins, ils entrent chacun à leur manière en résonance avec l'expérience particulière de nos enquêtés.

\subsection{Faire carrière malgré tout}

Une grande partie des efforts de ceux et celles qui ont vécu l'enseignement secondaire comme une relégation a été investie à essayer de conjurer, dans la mesure du possible, cette première (mes)orientation de leur carrière. Dans un environnement professionnel où l'agrégation est une des rares voies de promotion (Verneuil 2005), la plupart de nos enquêtés, qui sont déjà agrégés et bénéficient d'une relative ancienneté grâce à leurs quatre années à l'ENS comme " fonctionnaires stagiaires », ont, de fait, des perspectives d'évolution statutaire relativement réduites. La mobilité géographique et/ou la candidature sur des postes en CPGE ou dans une Section de technicien supérieur $\left(S T S^{12}\right)$, voire

12 Appellation qui regroupe les formations au Brevet de technicien supérieur (BTS) qu'elles se déroulent en lycée ou en Institut universitaire technologique (IUT) ouvertes aux personnes détentrices d'un baccalauréat technologique ou général. Pour une analyse de la place particulière qu'occupent ces

\section{Progression, "refusing to succeed," and the pursuit of a better "quality of life": three types of career path post-bifurcation}

In this final section, we will focus on different ways in which former students appropriate this rupture in the long term. The three types of career path described below are not specific to ENS students-and could, in our view, be applied to other secondary education teachers. Nevertheless, each resonates in its own way with the particular experience of the respondent.

\subsection{Having a career despite everything}

Those who have experienced secondary education as relegation have invested a great deal of effort into trying, as far as possible, to avert this first (mis)orientation of their career. In an environment in which the agrégation process is one of the few channels of promotion (Verneuil 2005), most of our respondents, having passed the exam and benefiting from relative seniority thanks to their four years at ENS as "trainee civil servants," have, in fact, relatively reduced perspectives regarding advancement of their career status. Geographical mobility and/or applying for CPGE teaching positions, or teaching advanced technical courses (Section de technicien supérieur, STS ${ }^{12}$ ), or even applying for positions in academic

12 This term brings together the different forms of the Brevet de technicien supérieur (BTS) technician certificate-whether studied in school or at a "University Institute of Technology' (Institut universitaire technologique, IUT) which is available to anyone with a technological or general baccalauréat. 
dans les services de l'inspection académique, ont bien souvent constitué les principales stratégies pour essayer de

« faire carrière » malgré tout.

Le parcours de Louis (L, CPGE, Paris, Fam+) est ici encore éclairant. Suite à sa première nomination, Louis a essayé à tout prix de « fuir » le lycée technique dans lequel il était en poste, en essayant de sortir de l'Éducation nationale dans un premier temps. Parallèlement à quelques « tentatives de reconversion " malheureuses en entreprise, Louis a également essayé de vivre de sa plume. En dehors de la poésie, qu'il pratique régulièrement depuis ses années de CPGE, il a ainsi écrit quelques livres pour adolescents et des manuels de vulgarisation philosophique. Mais aucun de ses ouvrages ne lui a permis d'envisager sérieusement de quitter

l'enseignement.

Finalement, Louis a profité d'une mutation de sa compagne - non-enseignante - en région parisienne pour demander une nouvelle affectation au titre du rapprochement de conjoint. Ce changement de région et d'établissement a fortement contribué à donner une nouvelle impulsion à sa carrière. En effet, une fois nommé dans le lycée général d'un quartier populaire de la proche banlieue parisienne, il a fait la connaissance d'un inspecteur général qui l'a fortement encouragé et soutenu pour obtenir le poste qu'il occupe aujourd'hui en CPGE. Dans cette nouvelle configuration, le titre de normalien et le capital symbolique qu'il représente

formations au sein de l'espace de l'enseignement supérieur français, nous renvoyons en particulier aux travaux de Sophie Orange (2013). inspection services very often constitute the main strategies normaliens employ to try to "pursue their career" despite everything.

Louis (A, CPGE, Paris, Fam+)'s career path is revealing again here. After his first appointment, Louis tried very hard to "escape" the technical college he was working at, first of all by trying to get out of the national education system. Along with several unsuccessful "attempts to convert" to business, Louis also tried out a career as a writer. Beside poetry, which he had written regularly since his CPGE years, he wrote several books for teenagers and popular philosophy guides. But none of his works allowed him to seriously consider leaving teaching.

In the end, Louis made use of the transfer of his-nonteacher-partner to the Paris region to request a new placement on the grounds of proximity to his partner. This change of region and establishment strongly contributed to giving a fresh impetus to his career. Indeed, once he was appointed to a general school in a popular district of Paris's inner suburbs, he became acquainted with an inspector general who strongly encouraged and supported him in obtaining the position he holds today in CPGE. In this new configuration, the title of normalien and the symbolic capital

For analysis of the special place within French higher education that this training holds, we would point you to the work of Sophie Orange (2013) in particular. 
ont joué « énormément », même si Louis confesse avoir dû vaincre sa " répugnance » à « copiner avec l'inspection générale » pour en profiter pleinement. Malgré ses seize années de «purgatoire », Louis se dit aujourd'hui très content de sa situation, tant au niveau de la qualité des élèves qu'il accueille en classe ( « je ne fais plus le même métier [que dans le technique], c'est clair ») que de son niveau de salaire : « avec les [heures supplémentaires en CPGE], j'augmente mon salaire de $20 \%$ - donc par rapport à mes camarades que je vois, qui sont directeurs de recherche au CNRS et qui sont payés à coups de pied aux fesses, [...] la prépa, à certains égards, c'est mieux. »

Cette dernière remarque appelle un commentaire. A l'instar de Louis, certains de nos enquêtés qui se sont éloignés de la carrière académique canonique (MCF/CR puis PU/DR) pour embrasser des parcours dans le secondaire ou dans l'enseignement post-baccalauréat (CPGE, STS), constatent qu'en matière de rétributions économiques et symboliques directes, ils ne sont pas nécessairement moins bien lotis que leurs anciens camarades. Sous cet angle, un poste dans une CPGE littéraire ou un bon lycée parisien peut en effet sembler plus enviable qu'un poste de MCF dans un IUT de province, pour prendre un exemple relativement caricatural. Néanmoins, à quelques exceptions près, les discours de ce type apparaissent à l'analyse comme des rationalisations ex post. En effet, les «choix » initiaux d'orientation professionnelle ont rarement été pensés en termes d'évaluation relative des rémunérations. it represents have played "a huge role," even if Louis admits to having had to get over his "aversion" to "getting pally with the inspection service" to be able to take full advantage of this. Despite his sixteen years of "purgatory," Louis says that he is very happy with his situation today, both in terms of the quality of students in his classes ("it's a totally different job [from the technical college], that's definite") and in terms of his salary: "With the [overtime in CPGE], I increase my salary by $20 \%$ - so compared with my course mates who I see, who are directors of research at CNRS and who are paid a pittance... in some ways teaching CPGE is better."

This last remark calls for comment. As in Louis's case, some of our respondents who have strayed from the conventional academic career (L/R then P/RD) to follow a career in secondary or post-baccalauréat (CPGE, STS) teaching, stated that in terms of direct economic and symbolic rewards, they are not necessarily worse off than their former classmates. From this perspective, an arts CPGE teaching position or one at a good Parisian school may indeed appear more desirable than a position as a lecturer at an IUT in the provinces, to take a somewhat extreme example. Nevertheless, with few exceptions, this type of argument appears to be ex post facto rationalisation when subjected to analysis. Indeed, the initial choices that were made regarding professional orientation were rarely on the grounds of an evaluation of relative pay. 


\subsection{Goût pour l'enseignement et « refus de parvenir »}

Un deuxième type de parcours repéré chez un plus petit contingent de nos enquêtés enseignants dans le secondaire est marqué par un fort investissement dans les activités pédagogiques, voire syndicales. Ce type de parcours est généralement associé à la revendication d'un attachement au secondaire et plus généralement à l'enseignement public. Celui-ci rappelle d'ailleurs l'attitude des élèves de SaintCloud qui, dans la première moitié xxe siècle, refusaient de céder aux " sirènes de l'agrégation » et de «parvenir »-i.e. de faillir à leur mission initiale d'enseignement auprès des classes populaires (Barbé \& Luc 1982).

C'est par exemple le cas de Martine (S, Sec, Paris, Fam $\uparrow$ ), enseignante en mathématiques dans un lycée de la région parisienne. À la suite de ses années à l'ENS, Martine a décidé de ne pas poursuivre en thèse et a été nommée sur le poste qu'elle occupe aujourd'hui. Cette orientation a été fortement informée par des motifs familiaux et genrés - Martine voulait être en priorité « disponible pour ses enfants » et enseigner en lycée lui semblait la meilleure option pour cela. Elle a envisagé à plusieurs reprises de se positionner sur des postes en IUT ou en BTS. Mais, ces postes étant tous situés à au moins une demi-heure de train de sa ville de résidence, elle n'est pas allée au bout de ses candidatures - préférant favoriser le temps passé avec son fils. Si Martine n'a jamais envisagé sérieusement de quitter le secondaire, c'est également parce qu'elle a développé un fort attachement à son travail et à son utilité (« [À l'origine,] je voulais faire du bénévolat... Je voulais absolument avoir un métier utile. Et je me sens utile en tant

\subsection{A taste for teaching and "refusing to succeed"}

A second type of career path followed by a smaller contingent of our secondary teacher respondents attests to a strong investment in the field of education or even in trade union activity. This type of career path is generally associated with a claim to being committed to secondary education teaching, and more generally to state education. It also recalls the attitude of students of Saint-Cloud, who, in the first half of the 20th century, refused to yield to the "call of the agrégation," and to "succeed"-i.e., a refusal to turn their backs on their founding mission of bringing education to the people (Barbé \& Luc 1982).

This, for example, was the case for Martine (S, Sec, Paris, Fam $\uparrow$ ), a maths teacher at a secondary school in the Paris region. After her years at ENS, Martine decided not to pursue a thesis, and was appointed to the position she has today. This choice was strongly influenced by family and gender factorsMartine's priority was to be "available for her children," and teaching at a school seemed to her the best option for this. She considered on several occasions positioning herself for IUT or BTS roles. But since these positions were all located at least a half-hour train journey from where she lived, she never went through with her applications-preferring to maximize the time spent with her son. Although Martine has never seriously considered leaving secondary teaching, it is just as much because she has developed a strong attachment to her work and her usefulness ("[Originally,] I wanted to do voluntary work... I really wanted to have a useful job. And I feel useful as a teacher.") This commitment-among others- 
que prof »). Cet engagement se manifeste entre autres par le temps qu'elle y consacre, maintenant que son fils est plus grand, en travaillant tous les jours de la semaine (weekend compris) et les soirées afin d'assurer un suivi maximum de ses élèves. Elle est également engagée dans certaines activités parascolaires, comme le club de théâtre du lycée, et accompagne régulièrement des classes dans les salles de spectacle de la région.

L'attachement à l'enseignement peut parfois prendre un ton plus politique, comme chez Alexia (L, Autre-, Prov, Fam $\uparrow$ ). Dans son cas, rester dans l'enseignement secondaire consistait à " essayer de mettre [son] capital culturel au service des jeunes " et à rapprocher " un maximum » ses élèves les moins favorisés « de la culture réservée à l'élite ". Représentante syndicale, elle a ainsi beaucoup milité pour maintenir certains enseignements rares (langues vivantes, arts...) dans le lycée rural où elle a été nommée à la fin de ses années à l'ENS, prenant position contre sa hiérarchie qui favorisait davantage les « classes d'élite » dans les «lycées de centre-ville ». Alexia regrette d'ailleurs que durant ses années d'études, l'environnement de l'ENS ne l'ait pas plus poussée à développer sa réflexion sur la pédagogie («j'ai l'impression d'avoir appris énormément, justement, en sortant de l'esprit dans lequel on était [à la fin des années passées

à l'ENS] $\gg)^{13}$

13 Cet attachement à l'enseignement et à la pédagogie peut également se manifester chez certains de nos enquêtés en poste dans le secondaire par l'écriture de manuels à destination des élèves. is apparent in the time she dedicates, now that her son is a bit older, to working every day of the week (including the weekend) and evenings in order to ensure maximum care and attention is given to her students. She is also involved in extracurricular activities, such as the school drama club, and regularly accompanies classes in theatres of the region.

The commitment to teaching can sometimes take on a more political tone, such as in the case of Alexia (A, Other-, Prov, Fam $\uparrow$ ). She said she stayed in secondary teaching to "try to put [her] cultural capital to use for the good of young people" and to bridge the gap "as far as possible" between her most disadvantaged students and "culture reserved for the elite." She is a union representative and has campaigned hard to maintain certain rarer subjects (languages, arts, etc) in the rural school where she was appointed at the end of her ENS years, taking a stand against the ENS establishment which favours the "elite classes" in "city-centre schools." Alexia also regrets that during her years of study, the ENS environment did not push her more to develop her thoughts on pedagogy ("I feel like I have learnt so much just by getting out of the mindset we were in [at the end of the years spent at ENS] ${ }^{13 ")}$.

13 This commitment to education and pedagogy may also be reflected in some of our respondents in secondary teaching posts through their writing of student textbooks. 
Cette forme d'engagement politique dans l'enseignement peut à l'occasion largement déborder du cadre strictement professionnel. Ainsi Alexia a-t-elle quitté l'enseignement secondaire quelques années avant l'entretien, au bénéfice d'un dispositif de retraite anticipée accessible aux mères de familles nombreuses. Elle utilise dorénavant son temps libre pour s'investir dans diverses associations écologistes de sa région. Dans la continuité de ses engagements d'enseignante, elle envisage de profiter de sa situation pour devenir « écrivaine publique ». Elle a également en projet l'écriture d'une pièce de théâtre fondée sur des récits de militants. Dans d'autres cas, l'engagement extra-professionnel peut prendre la forme d'un engagement politique dans les instances de pouvoir municipales notamment, où les anciens élèves peuvent réinvestir certains acquis de leur formation, notamment leur «force de travail » et leur capacité de synthèse comme le relève une de nos enquêtées, conseillère municipale d'une commune de l'Ouest parisien (Clothilde, L, CPGE, Fam+). Dans de pareilles situations, la bifurcation vers le secondaire semble pouvoir engendrer des formes d'investissement accrus dans certaines activités associatives ou politiques locales - et participe à pourvoir ces scènes politiques/publiques locales en intellectuels ordinaires.

\subsection{La « qualité de vie » avant tout}

Enfin, nous avons identifié un troisième type de parcours post-bifurcation, marqué par la recherche de la « qualité de vie ». Ce type de parcours est délicat à interpréter, la posture de relativisation dont font preuve nos enquêtés pouvant être une manière de faire de nécessité vertu. Mais elle ne s'y
This form of political commitment to teaching can from time to time spill far beyond a strictly professional context. Thus, Alexia had left secondary teaching several years before the interview, benefiting from an early retirement scheme available to mothers of large families. She has thereafter used her free time to get involved in various environmental organisations in her region. Following on from her commitments when she was a teaching, she intends to take advantage of her situation to become a "public writer and commentator." She is also working on writing a play based on activists' stories. In other cases, commitments outside of work can take the form of a political engagement at the level of municipal authorities, where former students can reinvest some of their experience from their training, especially their "labour power" and their capacity for synthesis, as noted by one of our respondents, a councillor in a commune in the west of Paris (Clothilde, A, CPGE, Fam+). In such situations, the bifurcation towards secondary teaching appears able to engender forms of increased investment in certain local organisations or political activities-and helps to supply these local political/public scenes with ordinary intellectuals.

\section{3. "Quality of life" first and foremost}

Finally, we identified a third type of career path postbifurcation that is characterized by the search for "quality of life." This type of choice is tricky to interpret since the position of relativization which our respondents demonstrate may be a way of making a virtue out of necessity. But it cannot be 
réduit pas, tant ce type d'aspiration « à une meilleure qualité de vie " nous semble révélateur de certains changements en cours dans les fractions intellectuelles supérieures des classes moyennes - et en particulier du côté des hommes.

Le cas de Xavier (S, Sec, Prov, Fam+), enseignant de mathématiques en lycée, est particulièrement intéressant de ce point de vue. Xavier compte au nombre de nos enquêtés qui s'autodéfinissent «pour rire » comme des « normaliens ratés ». Pour lui, fils et petit-fils d'agrégés d'une ville de l'Ouest de la France, l'intégration d'une ENS représentait tout d'abord l'opportunité de suivre un cursus sélectif et prestigieux. « La réalité du métier d'enseignant m'échappait totalement, même en ayant des parents profs " relève-t-il. Plus investi dans la guitare et les premiers pas de son groupe de rock que dans les activités académiques durant ses années à l'ENS («On pensait «on a eu le concours, c'est bon, on a fini «»), il a malgré tout réussi à décrocher l'agrégation et un contrat d'AND. Mais les résultats de sa thèse tardant à se dessiner, il s'est désintéressé progressivement de la recherche. II s'est ainsi retrouvé obligé de prendre un poste dans le secondaire directement après la fin de ses années de contrat d'AND et a fait sa première rentrée des classes dans un collège réputé difficile de la banlieue parisienne. Du fait du caractère peu anticipé de cette bifurcation, qui représentait alors tout au plus « un plan B », l'arrivée dans le secondaire a été « très dure » de son propre aveu (« je me souviens d'une envie de m'enfuir »). Après plusieurs années passées en région parisienne, Xavier et sa femme - elle-même normalienne et agrégée de lettres - ont décidé de demander une mutation only this, since this type of aspiration to a better quality of life seems to us to reveal certain changes under way in the upper intellectual echelons of the middle classes-and especially as far as men as concerned.

The case of Xavier (S, Sec, Prov, Fam+), a high school maths teacher, is particularly interesting from this point of view. Xavier is among a number of our respondents who define themselves "as a joke" as "failed normaliens." For him - the son and grandson of agrégés from the west of France-getting into ENS represented first and foremost an opportunity to do a selective and prestigious course. "The reality of a teaching career passed me by completely, even though there were teachers in my family," he admits. More interested in his guitar, and getting his rock group off the ground than in academic activities during his ENS years ("We thought 'we've passed the entrance exam, that's it, we've finished"'), he nevertheless passed the agrégation and obtained an AND contract. But when the results of his thesis were slow to materialize, he increasingly lost interest in research. He thus found himself forced to take a position in secondary education straight after the end of his contracted AND years and starting the academic year in September at a school that had a reputation for being difficult in the suburbs of Paris. The fact that this bifurcation was fairly unexpected-and represented at best a "plan B"meant that beginning secondary education teaching was "very tough," by his own admission ("I remember wanting to run away.") After several years in the Parisian region, Xavier and his wife-herself a normalienne agrégée-decided to request a transfer together to leave the capital and "buy a 
ensemble pour quitter la capitale et « acheter une maison " afin d'accueillir leur projet de famille nombreuse. Ils ont alors été nommés tous les deux dans le lycée et le collège de la petite ville qu'ils habitent au moment de l'entretien, au sud de

Paris.

Malgré un début de carrière compliqué et bien qu'il « ne se sente pas obligatoirement une vocation » pour l'enseignement - qu'il dit pratiquer essentiellement « parce que ça rapporte de l'argent »-, Xavier s'estime plutôt « chanceux ». II souligne notamment que lui et sa compagne gagnent « bien leur vie » avec leurs deux salaires d'agrégés. Bien que moins prestigieux que ceux de certains de leurs camarades de promotion, leur parcour professionnel leur a permis d'accéder à un certain confort de vie (acheter une maison, avoir un jardin, rentrer chez soi tous les soirs pour s'occuper des enfants ou jouer de la guitare...) qui leur aurait été difficilement accessible s'ils avaient tous les deux fait carrière à l'université.

" [À propos d'un de ses camarades de l'ENS] [II] adore son métier. C'est vraiment une passion [...]. Et à côté de ça, il en est à passer une à deux journées par semaine à l'hôtel [...] pour aller faire cours. II est dans des conditions matérielles déplorables. [...] Bon, il gagne bien sa vie aussi. Mais il a les gamins, il a la maison en banlieue parisienne qui coûte trois fois plus cher que la nôtre et à l'hôtel, il n'a même pas les toilettes dans la chambre... [...]. II est prof de fac, quoi. Donc c'est un beau métier, il fait des choses fascinantes des fois, il parle de choses intéressantes des fois à des élèves. Mais ce n'est pas toujours très intéressant. II n'a pas que des thésards [...]. II a aussi des [premiers cycles]. Enfin bon, je sais que ce n'est pas toujours fascinant. [...]. Donc, oui, quand je compare, oui, c'est vrai... J'aurais house" in order to accommodate their plan to have a large family. They were then appointed to the high school and the secondary school in the small town south of Paris where they were living at the time of the interview.

Despite the difficult start to his career, and although he "doesn't necessarily feel that teaching is [his] vocation"-he says he does it "because it brings in money"-Xavier feels he has been rather "lucky." He stresses, in particular, that he and his partner "earn a good living" with their two salaries combined. Although less prestigious than those of some of their classmates, their career path has allowed them to achieve a certain standard of living (buying a house, having a garden, coming home in the evening to look after the children or play the guitar...), which would have been harder for them to achieve had they both pursued a career in academia.

"[In reference to one of his ENS classmates] [He] loves his job. It's really his passion... And besides that, he spends one to two days a week at a hotel... so he can go and teach his classes. His living conditions are appalling... Ok, he earns a good living too. But he's got his kids, he's got the house on the outskirts of Paris which is three times the price of ours, and at the hotel he hasn't even got a toilet in his room... He's a university lecturer, you know? So, it's a nice job, sometimes he does fascinating things, and he talks about interesting things with his students from time to time. But it's not always very interesting. It's not just PhD students... There are [undergrads] too. Well anyway, I know it's not exactly fascinating all the time... So yes, when I compare, it's true... In some respects, l'd have liked a job in which I did 
aimé de certains côtés avoir un métier où je fais des maths, vraiment. [...] J'aurais aimé beaucoup de choses... J'aurais aimé être guitariste de rock aussi [rire]. »

Plus généralement, l'orientation professionnelle de Xavier après sa bifurcation vers le secondaire témoigne d'une aspiration à une vie personnelle de meilleure "qualité ", également au service d'une implication plus « marquée dans l'éducation de [ses] enfants " semblable à celle que Julie Jarty relève chez les enseignants de lycée « homogames » (Jarty 2009). L'analyse des logiques qui ont accompagné sa carrière post-ENS nous semble ainsi significative des mutations des représentations à l'œuvre au cours des vingt dernières années au sein des fractions intellectuelles supérieures des classes moyennes (Le Feuvre \& Lapeyre 2011). Son cheminement s'inscrit dans un « renouveau dans les pratiques à la fois professionnelles et familiales des hommes " de ces catégories sociales - sans engendrer toutefois une stricte équivalence et une totale interchangeabilité des rôles sexués traditionnels au sein de la gestion des affaires courantes de

leur vie familiale.

\section{Conclusion}

Au terme de cet article, on peut rappeler les différents résultats que la présente contribution permet d'établir. Premièrement, grâce à l'analyse quantitative, nous avons montré que les bifurcations durables des anciens élèves des ENS vers le secondaire ne se distribuent pas au hasard au sein de notre population d'enquête : elles sont en priorité le fait des femmes et de personnes issues de familles relativement peu maths, really... l'd have liked many things... l'd have liked to have been a rock guitarist too [laughs]."

More generally, Xavier's career path after his bifurcation towards secondary education attests to aspirations of a better "quality" of personal life, as well as to wanting to be more "involved in the education of [his] children" similar to that noted by Julie Jarty in "homogamous" high school teachers (Jarty 2009). Analysis of the pattern of his career post-ENS thus appears to us to be indicative of changes and representations at work over the past twenty years within the upper intellectual fractions of the middle classes (Le Feuvre \& Lapeyre, 2011). His path is part of a larger "renewal of both the professional and family role of men" in these social categories-without, however, engendering a strict equivalence or total interchangeability of traditional gender roles within the management of current affairs in their family life.

\section{Conclusion}

At the end of this article, let us recall the results that we have established. First, thanks to quantitative analysis, we have shown that the distribution of long-term bifurcations towards secondary teaching in the careers of former ENS students within our surveyed population is not random: such bifurcations are primarily seen in the case of women, and students from families who are relatively unprivileged in terms of academic 
dotées en capitaux scolaires et symboliques. Deuxièmement, l'analyse des entretiens montre que si l'engagement dans une carrière dans le secondaire est souvent présenté comme une rupture, la connotation plus ou moins négative et traumatique associée à cet événement est largement indexée sur les expériences sociales et scolaires préalables des enquêtés. Troisièmement, les effets à long terme de cette bifurcation sur les dynamiques des parcours professionnels se révèlent ici aussi largement pluriels : elle a pu engendrer des stratégies de reconquête d'un statut social prestigieux, des engagements à teneur politique dans l'enseignement ou dans des domaines extra-professionnels ou encore une mise

à distance relative des normes de la réussite.

Pour finir, nos résultats montrent que l'analyse de la construction sociale des classements et de la réputation n'épuise pas la compréhension des effets de ces verdicts socio-symboliques sur les personnes qui s'y soumettent. Ces classements sont l'objet de réappropriations diverses - elles-même informées par les logiques qui travaillent les parcours scolaires et professionnels individuels. Nos résultats plaident ainsi pour une inscription plus systématique de ces expériences dans le temps long des biographies individuelles, afin de saisir non seulement ce que fait l'apposition de marques de consécration aux individus mais également ce qu'ils et elles en font.

Cette remarque est particulièrement valable pour les travaux portant sur les élites scolaires françaises, où le fonctionnement du système scolaire qui sélectionne relativement tôt une « élite adolescente » (Eymeri 2005) destinée à occuper and symbolic capital. Second, analysis of the interviews shows that while taking up a career in secondary teaching is often presented as a rupture, the rather negative and traumatic connotation of this event is generally rooted in the former social and academic experiences of the respondents. Third, the long-term effects of this bifurcation on the evolution of the respondent's career are also generally shown here to be plural-the bifurcation may engender: strategies to win back a prestigious social status; political commitments within the context of teaching or which go beyond the professional sphere or even a distancing relative to standards of success.

Finally, our results show that analysis of the social construction of classand reputation does not fully equate to an understanding of the effects of these sociosymbolic judgements in those who propound them. These classifications are the object of various appropriations-which are themselves informed by rules governing individual academic and professional career paths. Our results thus call for these experiences to be systematically viewed within a longer-term, individual biographical context, to understand not only what the achievement of such status symbols does to individuals, but also what they do with them.

This point is particularly valuable for works that deal with French academic elites, where the functioning of the education system which selects an "adolescent elite" (Eymeri 2005), relatively early on, that is destined to fill dominant positions at 
précocement des positions dominantes porte à focaliser l'attention sur les conditions d'accès et le travail de « façonnage » opéré par ces formations plutôt qu'à étudier les étapes ultérieures des parcours. Mais ce constat vaut aussi dans d'autres cas nationaux. Ici encore, la sociologie des établissements d'élite américains en est une illustration particulièrement parlante. Dans les livres de Shamus Khan (2011) ou de Mitchell Stevens (2009), pour prendre deux exemples marquant parus ces dernières années sur le travail de socialisation au sein de différents colleges prestigieux, c'est avant tout la « production » par l'institution scolaire des futures élites nationales qui prédomine, comme le laisse très clairement apparaître les deux titres de leurs ouvrages (Creating a class pour Stevens, Privileges. The making of an adolescent elite pour Khan). À l'instar des recherches menées sur le cas français, ces ouvrages laissent ainsi largement dans l'ombre les effets au long terme de ce type de dispositif de sélection/formation - surestimant peut-être le

pouvoir d'homogénéisation de ces institutions.

Pour ces travaux et les futures recherches sur les élites scolaires et culturelles, les résultats présentés ici se voudraient une invitation à substituer à l'analyse de la construction/production d'un état particulier - « normalien », «polytechnicien » mais aussi « académicien », lauréats d'un prestigieux prix littéraire, etc., nécessairement « extraordinaires " - une approche plus attentive aux processus biographiques « ordinaires » dans lesquels s'inscrivent ces

épreuves de reconnaissance sociale.

Pierre Bataille

Université Libre de Bruxelles, Centre METICES http://metices.ulb.ac.be/ a young age invites us to focus on the conditions of entry and the "moulding" effect that this training has rather than studying the later stages of careers. But this observation also applies to cases in other countries. Here again, the sociology of elite American institutions is a particularly illustrative example. In the works of Shamus Khan (2011) and Mitchell Stevens (2009), to take two striking examples that have appeared in recent years on socialisation within different prestigious American colleges, it is first and foremost the "production" by the academic institution of future national elites which prevails, as the titles of these two works make very clear (Creating a Class by Stevens and Privilege: The Making of an Adolescent Elite by Khan). Like research conducted on the case of France, these works mostly ignore the long-term effects of this type of system of selection and training-overestimating, perhaps, these institutions' capacity to homogenize.

For these works and future research into academic and cultural elites, the results presented here thus intend to encourage a substitution of analysis of the construction/production of a particular status-such as normalien or polytechnicien (a student of the École Polytechnique engineering and military higher education institution), but also académicien, or the winner of a prestigious literary prize, etc. - which is necessarily "extraordinary," with an approach which pays greater attention to "ordinary" biographical processes within which these tests of social recognition fall.

Pierre Bataille Université Libre de Bruxelles, Centre METICES http://metices.ulb.ac.be/ 


\section{Références bibliographiques}

A3EPS (2013). « Des normaliens qui deviennent enseignants ou chercheurs... C'est grave docteur ? ». Movement \& Sport Sciences, 80 : 61-64.

AвBOtт Andrew (2010). « À propos du concept de Turning Point ». Traduit de l'anglais par Bernard Convert et Catherine Négroni. In BEssin Marc, BIDART Claire, GrossetTI Michel (dir.), Bifurcations. Les sciences sociales face aux ruptures et à l'événement. Paris, La Découverte, 187-211.

BARBÉ Alain \& Luc Jean-Noël (1982). Des Normaliens. Histoire de l'École normale supérieure de Saint-Cloud. Paris, Presses de Sciences-Po.

BATAILle Pierre (2013). « Mythe et réalités sociales du "dévoiement" des normaliens. L'exemple des École normales supérieures de Fontenayaux-Roses, Saint-Cloud et Lyon (1981-1987) ». Formation emploi, 121 : 107-126.

BATAILle Pierre (2014). Des cheminements sur la voie royale : une analyse sociologique des parcours de vie des normalien.ne.s de SaintCloud, Fontenay-aux-Roses et Lyon (1981-1987) (thèse de doctorat en sociologie). Lausanne, UNIL.

Baudelot Christian, Dethare Brigitte, Hérault Dominique, Lemaire Sylvie, RosenWALD Fabienne (2003). Les Classes préparatoires aux grandes écoles : évolutions sur vingt-cinq ans. Paris, DEP.

Baudelot Christian, Raux Hélène, Ritz Olivier, VINH Josianna (2005). «Que deviennent les normaliens à la sortie de l'école ? ». Bulletin de l'Association des Anciennes Elèves de l'ENS, Supplément historique.

Bidart Claire, Longo Maria-Eugenia, Mendez Ariel (2013). « Time and Process : An Operational Framework for Processual Analysis. » European Sociological Review, 29(4) : 743-751.

\section{References}

A3EPS (2013). "Des normaliens qui deviennent enseignants ou chercheurs... C'est grave docteur?." Movement \& Sport Sciences, 80: 61-64.

Aввотт, Andrew (1997). "On the Concept of Turning Point." Comparative Social Research, 16: 85-106.

BARBÉ Alain \& Luc Jean-Noël (1982). Des Normaliens. Histoire de l'École normale supérieure de Saint-Cloud. Paris, Presses de Sciences-Po.

BAtAille Pierre (2013). "Mythe et réalités sociales du 'dévoiement' des normaliens. L'exemple des École normales supérieures de Fontenayaux-Roses, Saint-Cloud et Lyon (1981-1987)." Formation emploi, 121 107-126.

BATAILLE Pierre (2014). Des cheminements sur la voie royale : une analyse sociologique des parcours de vie des normalien.ne.s de Saint-Cloud Fontenay-aux-Roses et Lyon (1981-1987) (PhD dissertation, Sociology). Lausanne, UNIL.

Baudelot Christian, Dethare Brigitte, Hérault Dominique, Lemaire Sylvie, RosenwaLd Fabienne (2003). Les Classes préparatoires aux grandes écoles: évolutions sur vingt-cinq ans. Paris, DEP.

Baudelot Christian, Raux Hélène, Ritz Olivier, VinH Josianna (2005). "Que deviennent les normaliens à la sortie de l'école?." Bulletin de l'Association des Anciennes Elèves de l'ENS, Supplément Historique.

Bidart Claire, Longo Maria-Eugenia, Mendez Ariel (2013). "Time and Process: An Operational Framework for Processual Analysis." European Sociological Review, 29(4): 743-751. 
BLANCHARD Marianne (2015). Les Écoles supérieures de commerce. Sociohistoire d'une entreprise éducative en France. Paris, Classiques Garnier.

Bond Matthew (2012). «The Bases of Elite Social Behaviour : Patterns of Club Affiliation among Members of the House of Lords ». Sociology $46(4): 613-632$

Bourdieu Pierre (1984). Homo Academicus. Paris, Minuit.

Bourdieu Pierre (1989). La Noblesse d'État. Paris, Minuit.

BusCATTO Marie \& MARRY Catherine (2009). « Le plafond de verre dans tous ses éclats. La féminisation des professions supérieures au $\mathrm{Xx}^{\mathrm{e}}$ siècle 》. Sociologie du travail, 51(2) : 170-182.

CACouAUlt-Bitaud Marlène (2007). Professeurs... mais femmes. Carrières et vies privées des enseignantes du secondaire au $x x^{e}$ siècle. Paris, La Découverte.

CASTETS-FonTAINE Benjamin (2011). « La randonnée vertueuse d'élèves de grandes écoles issus de "milieux populaires" ". L'Orientation scolaire et professionnelle, $40: 3-25$.

COUR DES COMPTES (2012). «Où vont les Écoles normales supérieures ? ». In Rapport public annuel 2012. Paris, Cour des Comptes : 553-598.

DARMON Muriel (2012). "Sélectionner, élire, prédire : le recrutement des classes préparatoires ». Sociétés contemporaines, $86: 5-29$.

Darmon Muriel (2013). Classes préparatoires : la fabrique d'une jeunesse dominante. Paris, La Découverte.
BLANCHARD Marianne (2015). Les Ecoles supérieures de commerce. Sociohistoire d'une entreprise éducative en France. Paris, Classiques Garnier.

Bond Matthew (2012). "The Bases of Elite Social Behaviour: Patterns of Club Affiliation among Members of the House of Lords." Sociology, 46(4): 613-632.

Bourdieu Pierre (1988). Homo Academicus. English translation by Peter Collier. Palo Alto, Stanford University Press.

Bourdieu Pierre (1998). The State Nobility: Elite Schools in the Field of Power. English translation by Lauretta C. Clough. Palo Alto, Stanford University Press.

BUSCATTO Marie \& MARRY Catherine (2009). "Le plafond de verre dans tous ses éclats. La féminisation des professions supérieures au $x x^{e}$ siècle." Sociologie du travail, 51(2): 170-182.

Cacouault-Bitaud Marlène (2007). Professeurs... mais femmes. Carrières et vies privées des enseignantes du secondaire au $x x^{e}$ siècle. Paris, La Découverte.

CASTETS-FontAINE Benjamin (2011). "La randonnée vertueuse d'élèves de grandes écoles issus de 'milieux populaires'." L'Orientation scolaire et professionnelle, 40: 3-25.

COUR DES COMPTES (2012). "Où vont les Écoles normales supérieures ?." In Rapport public annuel 2012. Paris, Cour des Comptes: 553-598.

DaRMON Muriel (2012). "Sélectionner, élire, prédire: le recrutement des classes préparatoires." Sociétés contemporaines, 86: 5-29.

DARMON Muriel (2013). Classes préparatoires: la fabrique d'une jeunesse dominante. Paris, La Découverte. 
DELIGNIÈRES Didier (2012). « Des normaliens pour quoi faire ? ». Movement \& Sport Sciences, $77: 1-3$.

DEMAZIÈRE Didier (2007). «Quelles temporalités travaillent les entretiens biographiques rétrospectifs ? ». Bulletin de Méthodologie Sociologique, $93: 5-27$.

EYMERI Jean-Michel (2001). La Fabrique des énarques. Paris, Economica

EYMERI Jean-Michel (2005). « La machine élitaire. Un regard européen sur le "modèle" français de fabrication des hauts fonctionnaires. » In JOLY Hervé (dir.), Formation des élites en France et en Allemagne. Cergy, Éditions du CIRAC : 101-128.

FERRAND Michèle, IMBERT Françoise, MARRY Catherine (1999). L'Excellence scolaire : une affaire de famille. Paris, L'Harmattan.

Galerand Elsa \& Kergoat Danièle (2008). « Le potentiel subversif du rapport des femmes au travail ». Nouvelles Questions Féministes, 27(2) : 67-82.

GoFFMAN Erving (1975). Stigmate. Les usages sociaux des handicaps. Traduit de l'anglais par Alain Kinm. Paris, Minuit.

GofFMAN Erving (1977). «La ritualisation de la féminité ». Traduit de l'anglais par Alain Kihm. Actes de la recherche en sciences sociales, 14 34-50.

Grousset-CharRIÈre Stéphanie (2012). La Face cachée de Havard. Paris, La Documentation Française.

HugRÉE Cédric (2010). « Le CAPES ou rien ? ». Actes de la recherche en sciences sociales, $183: 72-85$.
DELIGNIÈRES Didier (2012). "Des normaliens pour quoi faire?.” Movement \& Sport Sciences, 77: 1-3

DEMAZIĖRE Didier (2007). "Quelles temporalités travaillent les entretiens biographiques rétrospectifs?." Bulletin of Sociological Methodology, 93: 5-27.

EYMERI Jean-Michel (2001). La Fabrique des énarques. Paris, Economica

EYMERI Jean-Michel (2005). "La machine élitaire. Un regard européen sur le 'modèle' français de fabrication des hauts fonctionnaires". In JoLY Hervé (ed.), Formation des élites en France et en Allemagne. Cergy, Éditions du CIRAC: 101-128.

FERRAND Michèle, IMBERT Françoise, MARRY Catherine (1999). L'Excellence scolaire : une affaire de famille. Paris, L'Harmattan.

Galerand Elsa \& Kergoat Danièle (2008). "Le potentiel subversif du rapport des femmes au travail." Nouvelles Questions Féministes, 27(2): 67-82.

Goffman Erving (1963). Stigma: Notes on the on the Management of Spoiled Identity. London, Penguin.

GoFFMAN Erving (1977). "La ritualisation de la féminité." Translated by Alain Kihm. Actes de la recherche en sciences sociales, 14: 34-50.

Grousset-Charrière Stéphanie (2012). La Face cachée de Havard. Paris, La Documentation Française.

HugréE Cédric (2010). "Le CAPES ou rien?." Actes de la recherche en sciences sociales, 183: 72-85. 
JARTY Julie (2009). « Les usages de la flexibilité temporelle chez les enseignantes du secondaire ». Temporalités, 9. [En ligne] http:// temporalites.revues.org/1057 [consulté le 16 juin 2017].

KARABEL Jerome (2005). The chosen : The Hidden History of Admission and Exclusion at Harvard, Yale, and Princeton. Boston, Houghton Mifflin Company.

KHAN Shamus Rahman (2015). La Nouvelle École des élites. Traduction française par Damien-Guillaume Audollent et Marie-Blanche Audollent. Marseille, Agone.

LAMBERT Anne (2010). « Le comblement inachevé des écarts sociaux. Trajectoires et devenirs professionnels des élèves boursiers d'HEC et de I'ESSEC ». Actes de la recherche en sciences sociales, 183 : 106-124.

LE Bras Hervé (1983). «Les origines d'une promotion de Polytechniciens 》. Population, 38(3) : 491-502.

Le FeuVRE Nicky \& LAPEYRE Nathalie (2011). « Féminisation et aspiration à une meilleure "qualité de vie" : dynamique majeure des classes moyennes supérieures ». In Bouffartigue Paul, Gadéa Charles, Pochic Sophie (dir.), Cadres, classes moyennes : vers l'éclatement ?. Paris, Armand Colin : 224-233.

LetRAIT Muriel \& SALANE Fanny (2015). « Le temps consacré aux enfants les enseignantes et enseignants se distinguent-ils des autres diplômés de l'enseignement supérieur? ». Économie et statistique, 478 : 243-271.

MARRY Catherine (2004). Les Femmes ingénieurs, une révolution respectueuse. Paris, Belin.

Menger Pierre-Michel (2009). Le Travail créateur. S'accomplir dans l'incertain. Paris, Gallimard.
JARTY Julie (2009). "Les usages de la flexibilité temporelle chez les enseignantes du secondaire." Temporalités, 9. [On line] http://temporalites. revues.org/1057 [accessed on 16 june 2017].

Karabel Jerome (2005). The chosen: The Hidden History of Admission and Exclusion at Harvard, Yale, and Princeton. Boston, Houghton Mifflin Company.

KHAN Shamus Rahman (2011). Privilege: The Making of an Adolescent Elite at St. Paul's School. Princeton, Princeton University Press.

LAMBERT Anne (2010). "Le comblement inachevé des écarts sociaux. Trajectoires et devenirs professionnels des élèves boursiers d'HEC et de I'ESSEC." Actes de la recherche en sciences sociales, 183: 106-124.

LE Bras Hervé (1983). "Les origines d'une promotion de Polytechniciens." Population, 38(3): 491-502.

Le Feuvre Nicky \& Lapeyre Nathalie (2011). "Féminisation et aspiration à une meilleure 'qualité de vie': dynamique majeure des classes moyennes supérieures." In Bouffartigue Paul, GadÉA Charles, Pochic Sophie (eds.), Cadres, classes moyennes: vers l'éclatement?. Paris, Armand Colin: 224-233.

Letrait Muriel \& Salane Fanny (2015). "Le temps consacré aux enfants: les enseignantes et enseignants se distinguent-ils des autres diplômés de l'enseignement supérieur?." Économie et statistique, 478: 243-271.

MARRY Catherine (2004). Les Femmes ingénieurs, une révolution respectueuse. Paris, Belin.

Menger Pierre-Michel (2014). The Economics of Creativity. English translation by Steven Rendall. Cambridge, Harvard University Press. 
Orange Sophie (2013). L'Autre Enseignement supérieur : les BTS et la gestion des aspirations scolaires. Paris, Presses Universitaires de France.

OULHIOU Yvonne (1981). "L'École normale supérieure de Fontenay-auxroses à travers le temps, 1880-1980 ". Les Cahiers de Fontenay, horssérie. Fontenay-aux-roses, ENS Édition.

Pasqual Paul (2014). Passer les frontières sociales : comment les " filières d'élite » entrouvrent leurs portes. Paris, Fayard.

PAVIS Fabienne (2013). "Les anciens élèves des sections économiques de l'ENSET/ENS Cachan : quel devenir professionnel ? (promotions 1975-1995) ». In LE BOT Florent, ALBE Valérie, Bodé Gérard, BRUCY Guy, CHATEL Elisabeth (dir.), L'ENS Cachan. Le siècle d'une grande école pour les sciences, les techniques, la société. Rennes, Presses Universitaires de Rennes : 197-216.

Pierrel Arnaud (2015). «Réussite scolaire, barrière économique. Des boursiers et leur famille face aux frais de scolarité des grandes écoles de commerce ». Sociologie, 6(3) : 225-240.

QuéRÉ Olivier (2015). « La fabrique des cadres intermédiaires de la fonction publique ». Gouvernement et action publique, 2015/4 : 33-54.

SchotTé Manuel (2012). La Construction du «talent " : sociologie de la domination des coureurs marocains. Paris, Raisons d'agir.

SingLY François (DE) (1987). Fortune et infortune de la femme mariée. Paris, Presses Universitaires de France.

SIRINELLI Jean-François (1988). Génération intellectuelle : khâgneux et normaliens dans l'entre-deux-guerres. Paris, Fayard.

SOARES Joseph A. (1999). The Decline of Privilege : The Modernization of Oxford University. Palo Alto, Stanford University Press.
ORANGE Sophie (2013). L'Autre Enseignement supérieur: les BTS et la gestion des aspirations scolaires. Paris, Presses universitaires de France.

OULHIOU Yvonne (1981). "L'École normale supérieure de Fontenay-auxroses à travers le temps, 1880-1980." Les Cahiers de Fontenay, horssérie. Fontenay-aux-roses, ENS Édition.

PASQUALI Paul (2014). Passer les frontières sociales: comment les "filières d'élite" entrouvrent leurs portes. Paris, Fayard.

Pavis Fabienne (2013). "Les anciens élèves des sections économiques de l'ENSET/ENS Cachan : quel devenir professionnel ? (promotions 19751995)." In Le Bot Florent, Albe Valérie, Bodé Gérard, BRucy Guy, CHATEL Elisabeth (eds.), L'ENS Cachan. Le siècle d'une grande école pour les sciences, les techniques, la société. Rennes, Presses Universitaires de Rennes: 197-216.

Pierrel Arnaud (2015). "Réussite scolaire, barrière économique. Des boursiers et leur famille face aux frais de scolarité des grandes écoles de commerce." Sociologie, 6: 225-240.

QUÉRÉ Olivier (2015). "La fabrique des cadres intermédiaires de la fonction publique." Gouvernement et action publique, 2015/4: 33-54.

SCHOtTÉ Manuel (2012). La Construction du "talent": sociologie de la domination des coureurs marocains. Paris, Raisons d'agir.

SINGLY François (DE) (1996). Modern Marriage and its Cost to Women: A Sociological Look at Marriage in France. English translation by Malcom Bailey. Newark, University of Delaware Press.

SIRINELLI Jean-François (1988). Génération intellectuelle: khâgneux et normaliens dans l'entre-deux-guerres. Paris, Fayard.

SOARES Joseph A. (1999). The Decline of Privilege: The Modernization of Oxford University. Palo Alto, Stanford University Press. 
Stevens Mitchell L. (2009). Creating a Class : College Admissions and the Education of Elites. Cambridge, Londres, Harvard University Press.

Verneull Yves (2005). Les Agrégés. Histoire d'une exception française. Paris, Belin.

Zimdars Anna, Sullivan Alice, Heath Anthony (2009). « Elite Higher Education Admissions in the Arts and Sciences : is Cultural Capital the Key ? ». Sociology, 43(4) : 648-666.
STEVENS Mitchell L. (2009). Creating a Class: College Admissions and the Education of Elites. Cambridge, London, Harvard University Press.

VerneUIL Yves (2005). Les Agrégés. Histoire d'une exception française. Paris, Belin.

Zimdars Anna, Sullivan Alice, Heath Anthony (2009). "Elite Higher Education Admissions in the Arts and Sciences: is Cultural Capital the Key?." Sociology, 43(4): 648-666. 